\title{
Simultaneous Screening of 24 Target Genes of Foodborne Pathogens in 35 Foodborne Outbreaks Using Multiplex Real-Time SYBR Green PCR Analysis
}

\author{
Hiroshi Fukushima, ${ }^{1}$ Jun Kawase, ${ }^{1}$ Yoshiki Etoh, ${ }^{2}$ Kumiko Sugama, ${ }^{3}$ Shunshuke Yashiro, ${ }^{4}$ \\ Natsuko Iida, ${ }^{5}$ and Keiji Yamaguchi ${ }^{6}$ \\ ${ }^{1}$ Shimane Prefectural Institute of Public Health and Environmental Science, 582 Nishihamasada, Matsue, Shimane 690-0122, Japan \\ ${ }^{2}$ Fukuoka Institute of Health and Environmental Sciences, 39 Mukaizano, Dazaifu, Fukuoka 818-0135, Japan \\ ${ }^{3}$ Fukushima Institute of Public Health, 16-6 Houkida-aza-mitouchi, Fukushima 960-8560, Japan \\ ${ }^{4}$ Kumamoto Prefectural Institute of Health and Environmental Science, 1240-1 Kurisaki, Udo, Kumamoto 869-0425, Japan \\ ${ }^{5}$ Shizuoka Institute of Environment and Hygiene, 4-27-2 Kitayasuhigashi, Aoi, Shizuoka 420-8637, Japan \\ ${ }^{6}$ Hokkaido Institute of Public Health, West 12, Nortb 19, North Ward, Sapporo, Hokkaido 060-0819, Japan
}

Correspondence should be addressed to Jun Kawase, kawase-jun@pref.shimane.lg.jp

Received 16 February 2010; Revised 8 June 2010; Accepted 5 July 2010

Academic Editor: Susana Merino

Copyright (C) 2010 Hiroshi Fukushima et al. This is an open access article distributed under the Creative Commons Attribution License, which permits unrestricted use, distribution, and reproduction in any medium, provided the original work is properly cited.

\begin{abstract}
A set of 8 multiplex real-time SYBR Green PCR (SG-PCR) assays including 3 target primers and an internal amplification control (IAC) primer was simultaneously evaluated in $3 \mathrm{~h}$ or less with regard to detection of 24 target genes of 23 foodborne pathogens in 7 stool specimens of foodborne outbreak using a 96-well reaction plate. This assay, combined with DNA extraction (QIAamp DNA Stool Mini kit), offered detection of greater than $10^{3}-10^{4}$ foodborne pathogens per $g$ in stool specimens. The products formed were identified using melting point temperature $(\mathrm{Tm})$ curve analysis. This assay was evaluated for the detection of foodborne pathogens in 33 out of 35 cases of foodborne outbreak, using 4 different PCR instruments in 5 different laboratories. No interference from the multiplex real-time SG-PCR assay, including IAC, was observed in stool specimens in any analysis. We found multiplex real-time SG-PCR assay for simultaneous detection of 24 target genes of foodborne pathogens to be comprehensive, rapid, inexpensive, accurate, of high selectivity, and good for screening probability.
\end{abstract}

\section{Introduction}

Technological advances in the past 2 decades have substantially increased the possibility of rapid diagnostic testing for many diseases. However, for bacterial pathogens which cause foodborne infections or foodborne outbreaks, traditional culture methods, which can take up to 1 week, are still the only method many microbiology laboratories routinely use for diagnosis [1]. Real-time PCR is one of the principle methodologies emerging for rapid diagnosis of foodborne outbreak. We previously reported a duplex real-time SYBR Green PCR (SG-PCR) screening system of 8 specific genes of foodborne pathogens in 5 fecal samples [2-4]. The realtime SG-PCR assay combined with DNA extraction using a QIAamp DNA Stool Mini kit offered detection of greater than $10^{3}-10^{4}$ foodborne pathogens per $\mathrm{g}$ in fecal samples. For diagnosis and management of foodborne outbreaks, this could distinguish patients infected with foodborne pathogens from healthy carriers. The introduction of this screening system in foodborne outbreak investigations provides an opportunity for comprehensive and rapid detection of pathogens in fecal samples. The results can quickly inform a public health administrator about the causative pathogens of foodborne outbreak, allowing a more accurate, effective and timely response. If it is possible to test for almost all foodborne pathogens including enteric and toxin-producing bacteria at a time, real-time PCR tests will certainly be useful for multiplex screening of foodborne pathogens. 


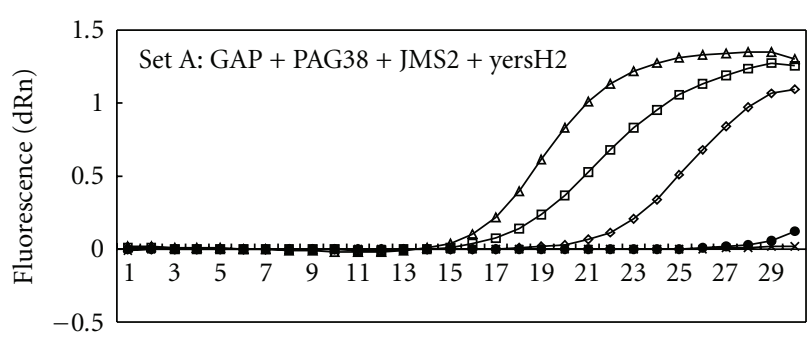

Cycle number

$\begin{array}{ll}\rightarrow \text { NC } & \square \text { P. alcalifaciens } \\ \rightarrow \text { IAC } & \rightarrow \text { EHEC (Stx 2) } \\ \square \text { C. perfringens } & \end{array}$

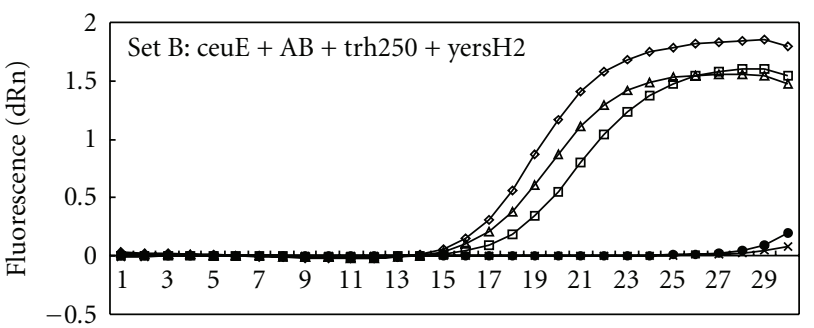

Cycle number
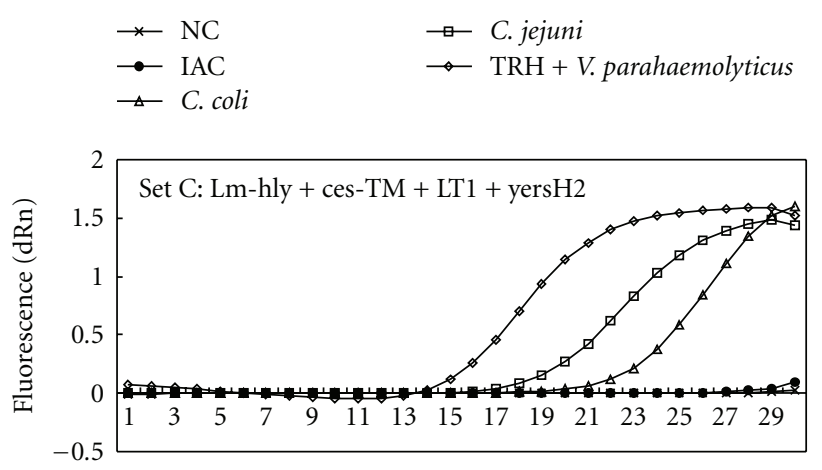

Cycle number

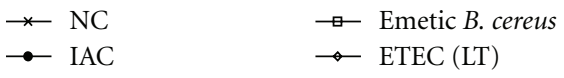

$\triangle$ L. monocytogenes

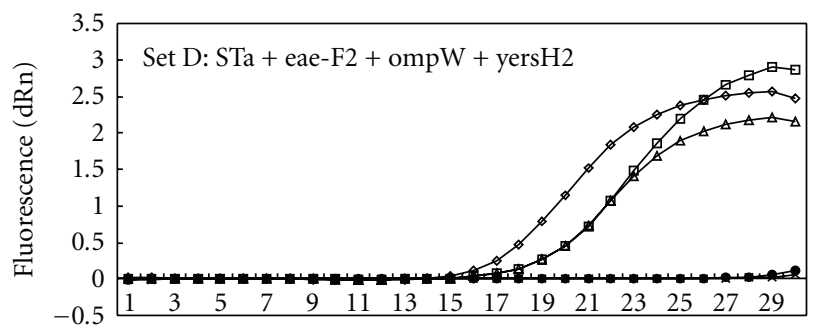

Cycle number

$\begin{array}{ll}\rightarrow \text { NC } & \rightarrow \text { EPEC } \\ \rightarrow \text { IAC } & \rightarrow \text { V. cholerae } \\ \rightarrow \text { ETEC (ST) } & \end{array}$

(a)

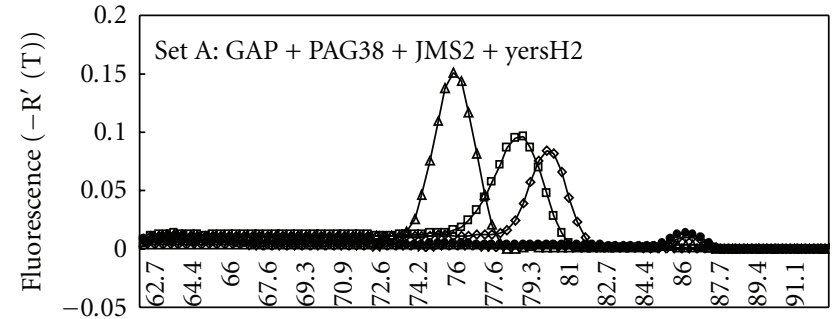

Temperature $\left({ }^{\circ} \mathrm{C}\right)$

$$
\begin{aligned}
& \rightarrow \text { NC } \quad \rightarrow \text { P. alcalifaciens } \\
& \rightarrow \text { IAC } \rightarrow \text { EHEC (Stx 2) } \\
& \triangle \text { C.perfringens }
\end{aligned}
$$

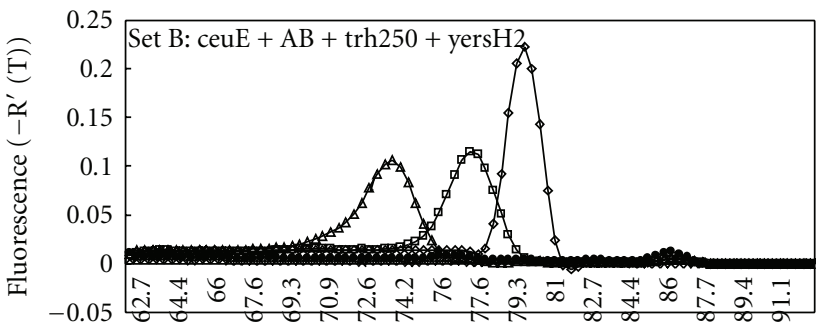

Temperature $\left({ }^{\circ} \mathrm{C}\right)$

$$
\begin{array}{ll}
\rightarrow \text { NC } & \square \text { C. jejuni } \\
\rightarrow \text { IAC } & \rightarrow \text { TDH }+ \text { V. parahaemolyticus } \\
\triangle \text { C. coli } &
\end{array}
$$

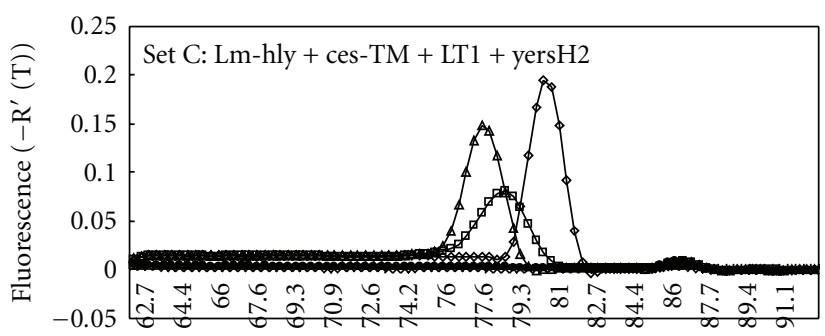

Temperature $\left({ }^{\circ} \mathrm{C}\right)$

$$
\begin{aligned}
& \rightarrow \text { NC } \rightarrow \text { Emetic B. cereus } \\
& \rightarrow \text { IAC } \rightarrow \text { ETEC (LT) }
\end{aligned}
$$

$\triangle$ L. monocytogenes

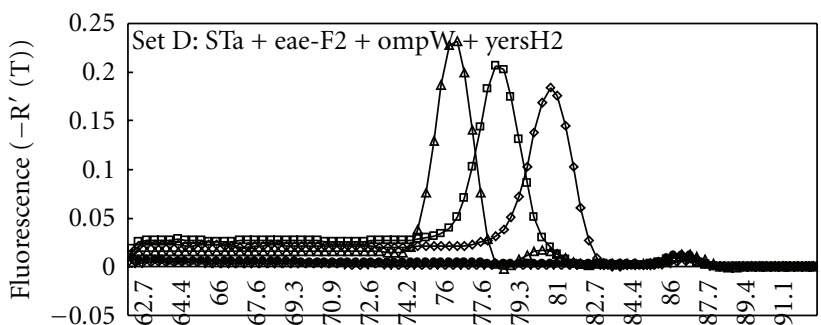

Temperature $\left({ }^{\circ} \mathrm{C}\right)$

$$
\begin{array}{ll}
* \text { NC } & \rightarrow \text { EPEC } \\
\rightarrow \text { IAC } & \rightarrow \text { V.cholerae } \\
\square \text { ETEC (ST) } &
\end{array}
$$

(b)

Figure 1: Continued. 


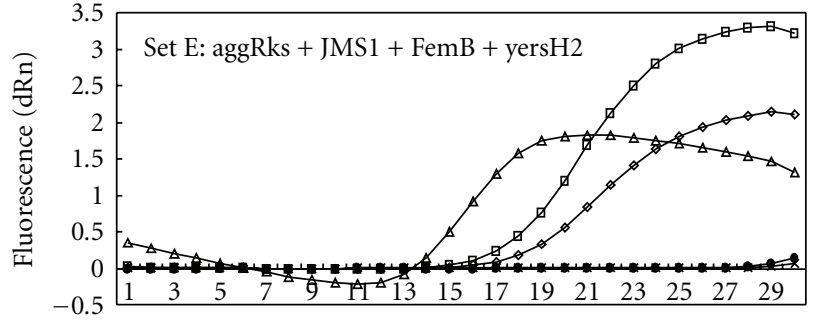

Cycle number

$$
\begin{array}{ll}
\rightarrow \text { NC } & \rightarrow \text { EHEC }(\text { Stx 1) } \\
\rightarrow \text { IAC } & \rightarrow \text { S. aureus } \\
\square \text { EAEC } &
\end{array}
$$

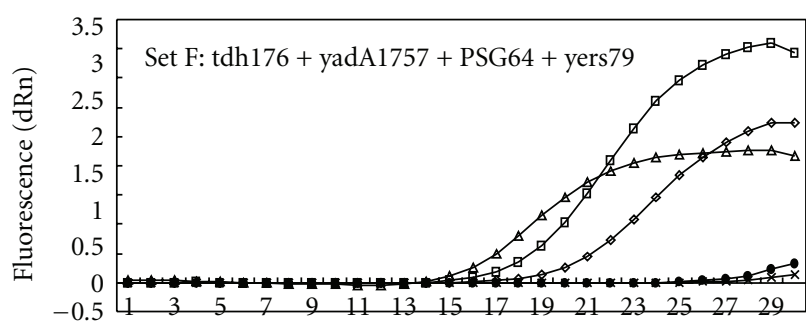

Cycle number

$$
\begin{aligned}
& * \text { NC } \\
& \rightarrow \text { IAC } \\
& \rightarrow \text { TDH + V.parahaemolyticus }
\end{aligned}
$$

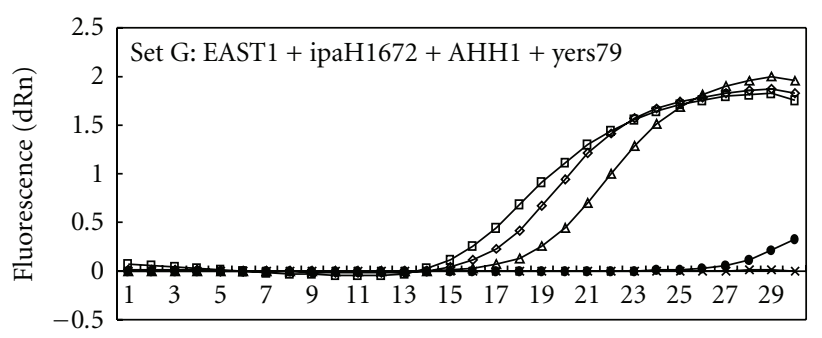

Cycle number

$$
\begin{aligned}
& \star \text { NC } \\
& \rightarrow \text { IAC } \\
& \unlhd \text { EAEC }
\end{aligned}
$$

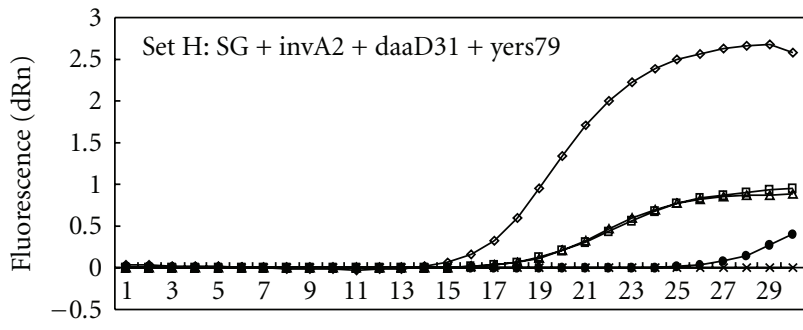

Cycle number

$$
\begin{aligned}
& * \text { NC } \quad \rightarrow \text { S. Enteritidis } \\
& \rightarrow \text { IAC } \rightarrow \text { DAEC } \\
& \triangle \text { Enterotoxigenic B. cereus }
\end{aligned}
$$

(a)

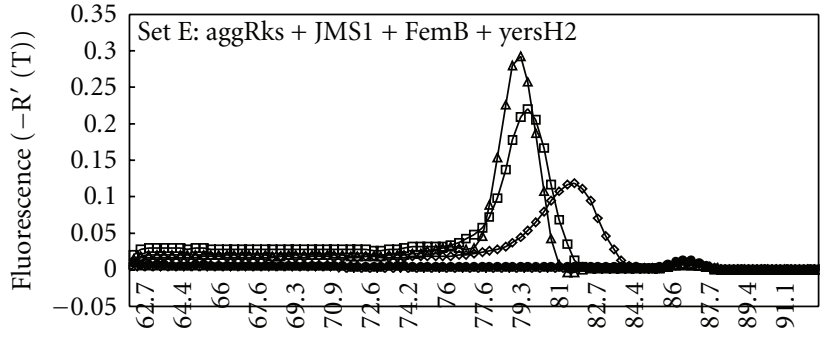

Temperature $\left({ }^{\circ} \mathrm{C}\right)$

$$
\begin{array}{ll}
\rightarrow \text { NC } & \rightarrow \text { EHEC }(\text { Stx 1) } \\
\rightarrow-\text { IAC } & \rightarrow \text { S. aureus } \\
\triangle \text { EAEC } &
\end{array}
$$

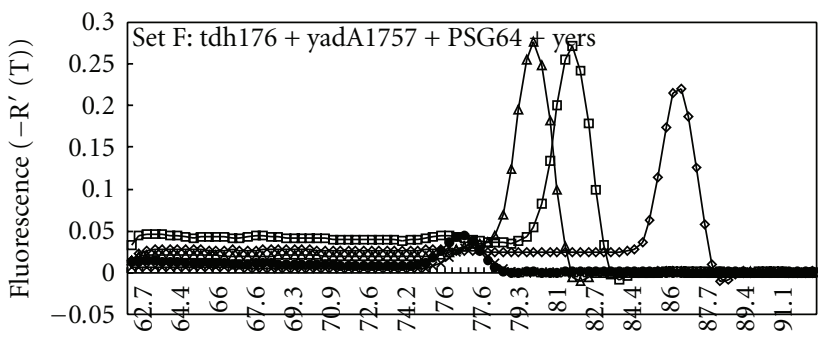

Temperature $\left({ }^{\circ} \mathrm{C}\right)$

$$
\begin{aligned}
& \rightarrow \text { NC } \\
& \rightarrow \text { IAC } \\
& \rightarrow \text { TDH + V.parahaemolyticus }
\end{aligned}
$$

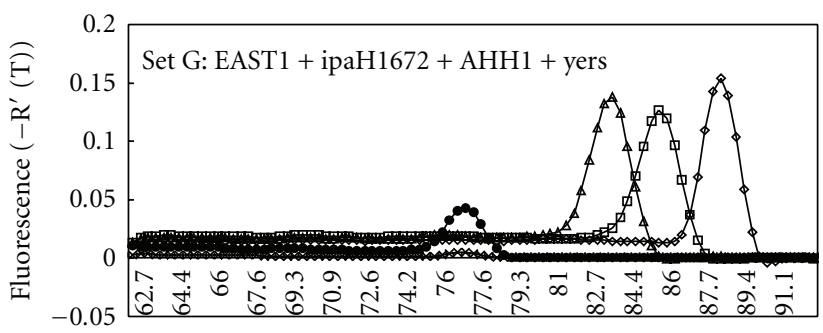

Temperature $\left({ }^{\circ} \mathrm{C}\right)$

$$
\begin{aligned}
& \rightarrow \text { NC } \rightarrow \text { EIEC } \\
& \rightarrow \text { IAC } \\
& \rightarrow \text { A. hydrophila } \\
& \triangle \text { EAEC }
\end{aligned}
$$

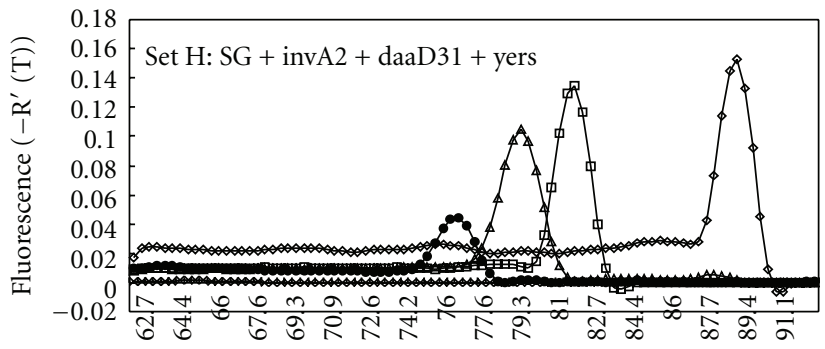

Temperature $\left({ }^{\circ} \mathrm{C}\right)$

$$
\begin{aligned}
& * \text { NC } \\
& \rightarrow \text { IAC } \\
& \triangle \text { Enterotoxigenic B. cereus }
\end{aligned}
$$

(b)

Figure 1: Amplification (a) and melting curve analysis (b) of 3 target genes of foodborne pathogens and IAC gene by primer sets A to H in multiplex real-time SG-PCR. 
With multiplex PCR tests, if multiple bacteria could be simultaneously detected in the same reaction tube or during the same run, molecular diagnosis may prove to be very costeffective. However, at present, published evaluations of these assays are insufficient.

One of the risks associated with testing samples by PCR is the occurrence of a false negative resulting from PCR inhibition $[5,6]$. While positive and negative controls are normally run with every PCR master mix to ensure integrity of the reagents, PCR inhibition by the sample matrix can prevent amplification of the target template, resulting in false-negative reporting $[5,6]$. Therefore, it is necessary to include an internal amplification control (IAC) in each individual reaction mixture to prevent reporting of false negatives [5]. Previous works have utilized various methods for developing and using an IAC for detection of a single target gene, except in the case of 4target TaqMan multiplex PCR to detect $V$. parahaemolyticus [7].

The objective of the present study was to establish simple and specific methods to simultaneously detect 24 specific genes of foodborne pathogens in 7 stool specimens in a realtime SG-PCR assay using a 96-well reaction plate containing a universal, noncompetitive IAC.

\section{Materlal and Methods}

2.1. Bacterial Strains. The 659 foodborne pathogens used in this study are shown in Table 2 . The 23 foodborne pathogens (enteroinvasive Escherichia coli, enteropathogenic E. coli, enterohemorrhagic E. coli, enterotoxigenic E. coli, enteroaggregative E. coli, diffusively adherent E. coli, Shigella spp., Salmonella spp., Yersinia enterocolitica, Y. pseudotuberculosis, Providencia alcalifaciens, Plesiomonas shigelloides, Campylobacter jejuni, C. coli, Vibrio cholerae, TDH-positive $V$. parahaemolyticus, TRH-positive V. parahaemolyticus, Aeromonas hydrophila, Staphylococcus aureus, emetic Bacillus cereus, enterotoxigenic B. cereus, Clostridium perfringens, and Listeria monocytogenes) described as control strain in Table 2 are used as control for PCR analysis. DNA was isolated from cultured bacteria to test the specificity of the primers used in this study. Viable counts were obtained by culturing each dilution $(10 \mu \mathrm{L})$ overnight at $37^{\circ} \mathrm{C}$ on tryptic soy agar (TSA) plates for aerobic bacteria and TSA plates containing $3 \% \mathrm{NaCl}$ for Vibrio spp. Yersinia spp. strains were cultured at $28^{\circ} \mathrm{C}$ for $48 \mathrm{~h}$. The Clostridium perfringens strains were cultured on TSA overnight at $37^{\circ} \mathrm{C}$ using anaerobic conditions. The Campylobacter jejuni strains were cultured at $37^{\circ} \mathrm{C}$ for $48 \mathrm{~h}$ on Skirrow agar plates under microaerobic conditions.

2.2. Internal Amplification Control (IAC) and IAC Primers for PCR. An IAC was included in the assay by adding a small amount of PCR products using IAC primers from the bacterium Yersinia ruckeri (JCM15110), which is the causative agent of enteric red-mouth disease in salmonid fish species [8] and the presence of this bacterium in human fecal samples and food samples is never reported. Bacterium used for DNA extraction was grown on brain heart infusion broth (Difco) at $30^{\circ} \mathrm{C}$ for 2 days. Two IAC primer pairs with different Tm of PCR products were used for amplifying $16 \mathrm{~S}$ rRNA gene (GenBank accession no. X75275) of Y. ruckeri. One IAC primer was yers described by Lund et al. [9] and the $\mathrm{Tm}$ value of PCR product used for this primer was $77.3 \pm 0.15^{\circ} \mathrm{C}$. Another IAC primer sequence of yers $\mathrm{H} 2-\mathrm{F}$ and yers $\mathrm{H} 2-\mathrm{R}$ were chosen by alignment of $16 \mathrm{~S}$ rRNA gene sequence from foodborne pathogens shown in Table 1 using the BLAST program within GenBank and was designed by Biosearch Technologies Inc. The Tm value of PCR product used for this primer was $86.0 \pm 1.5^{\circ} \mathrm{C}$.

2.3. DNA Extraction. For the DNA isolation from bacterial cultures, one milliliter of broth culture was centrifuged at $12,000 \times g$ for 3 minutes. The pellet was then washed in $1 \mathrm{~mL}$ of distilled water, centrifuged, and suspended into $1 \mathrm{~mL}$ of distilled water. Each 200 microliters of suspension, containing $10^{8}$ foodborne bacterial cells, was treated with the QIAamp DNA Stool Mini kit (Qiagen) according to manufacturer instructions. DNA preparations were used immediately for PCR amplification and stored at $-20^{\circ} \mathrm{C}$. Four $\mu \mathrm{L}$ of DNA sample were used for PCR assay. For the DNA isolation from stool samples, stool samples (1 g) were weighed aseptically, placed into sterile tubes, and homogenized with $9 \mathrm{~mL}$ of distilled water. Two-hundred $\mu \mathrm{L}$ of this stool suspension was treated with the QIAamp DNA Stool Mini kit according to manufacturer instructions in $1 \mathrm{~h}$ or less.

2.4. Primers. Primers were used for 24 specific genes of 23 foodborne pathogens which belonged to 16 species: Escherichia coli (enteroinvasive E. coli, enteropathogenic E. coli, enterohemorrhagic E. coli, enterotoxigenic E. coli, enteroaggregative E. coli, and diffusively adherent E. coli), Shigella spp., Salmonella spp., Yersinia enterocolitica, Y. pseudotuberculosis, Providencia alcalifaciens, Plesiomonas shigelloides, Campylobacter jejuni, C. coli, Vibrio cholerae, V. parahaemolyticus (TDH-positive and TRH-positive types), Aeromonas hydrophila, Staphylococcus aureus, Bacillus cereus (emetic and enterotoxigenic types), Clostridium perfringens, and Listeria monocytogenes, and the 2 IAC primers are listed in Table 1. The size and melting point temperature ( $\mathrm{Tm})$ values of PCR products are also listed in Table 1. The specificity and sensitivity of PCR assay using each primer were confirmed in each referred report. The primer pairs of tdhF176 and tdh-R422 for the detection of $t d h$-positive $V$. parahaemolyticus, yadA-F1757 and yadA-R1885 for the detection of Y. enterocolitica and Y. pseudotuberculosis, PSG-F64 and PSG-R313 for the detection of $P$. shigelloides, ipaH1672-F and ipaH1761-R for the detection of Shigella spp., and EIEC, daaD-F31 and daaD-R263 for the detection of DAEC were chosen by alignment of virulent or specific gene sequences from foodborne pathogens shown in Table 2 using the BLAST (Basic Local Alignment Search Tool) program within GenBank and was designed by Biosearch Technologies Inc. (Tokyo). The $T m$ values of these primers varied from 74.5 to 88.7. 


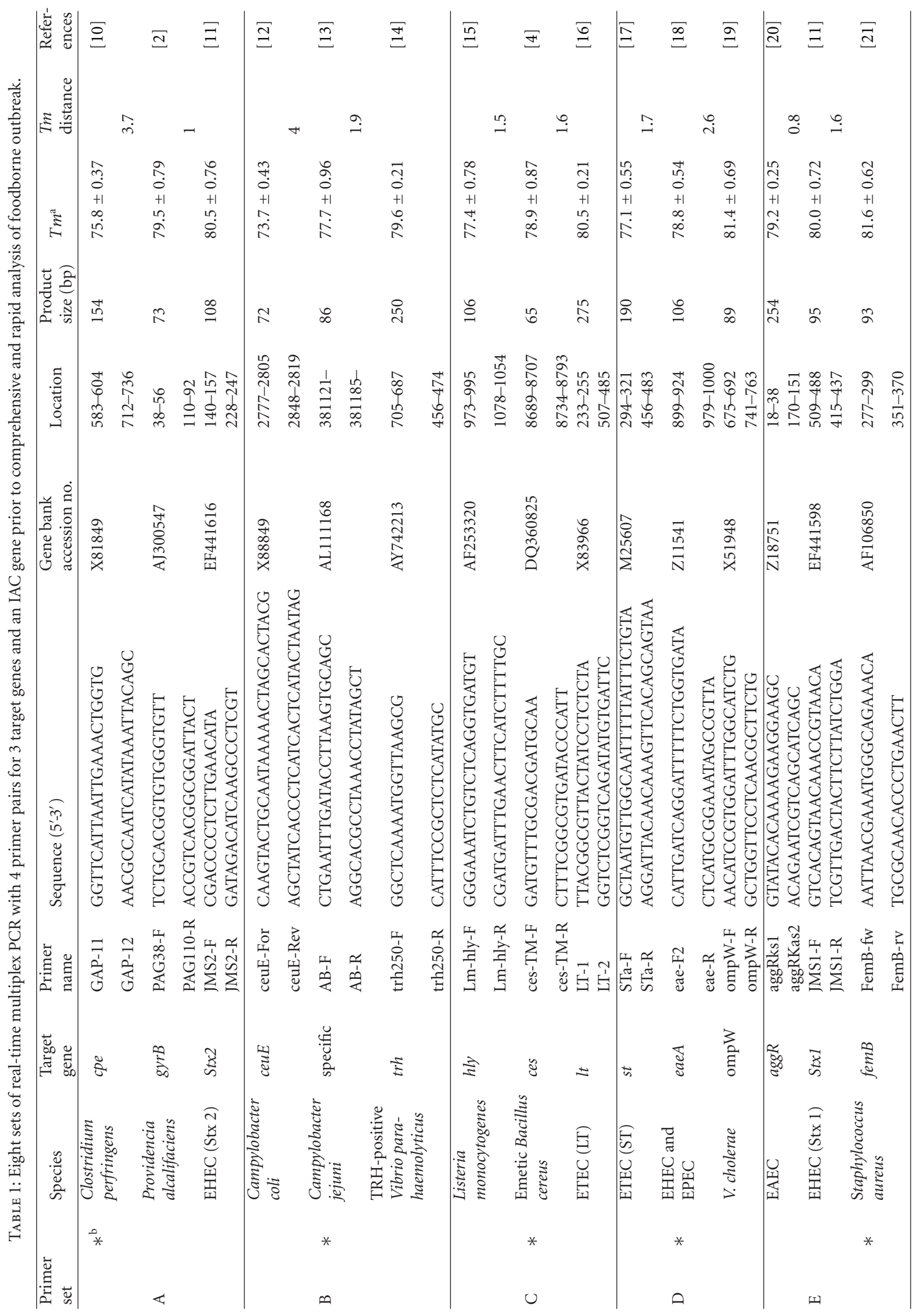




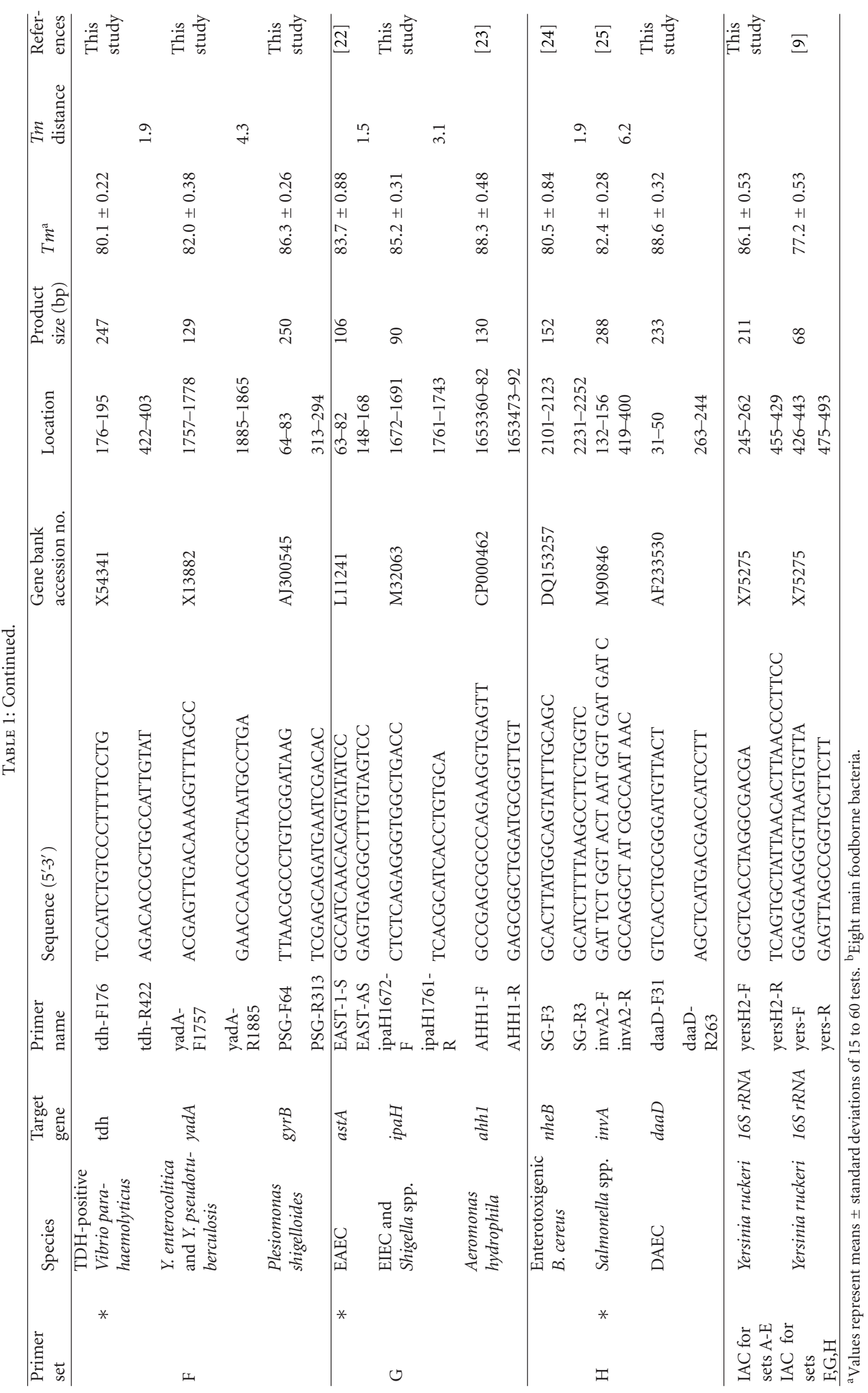




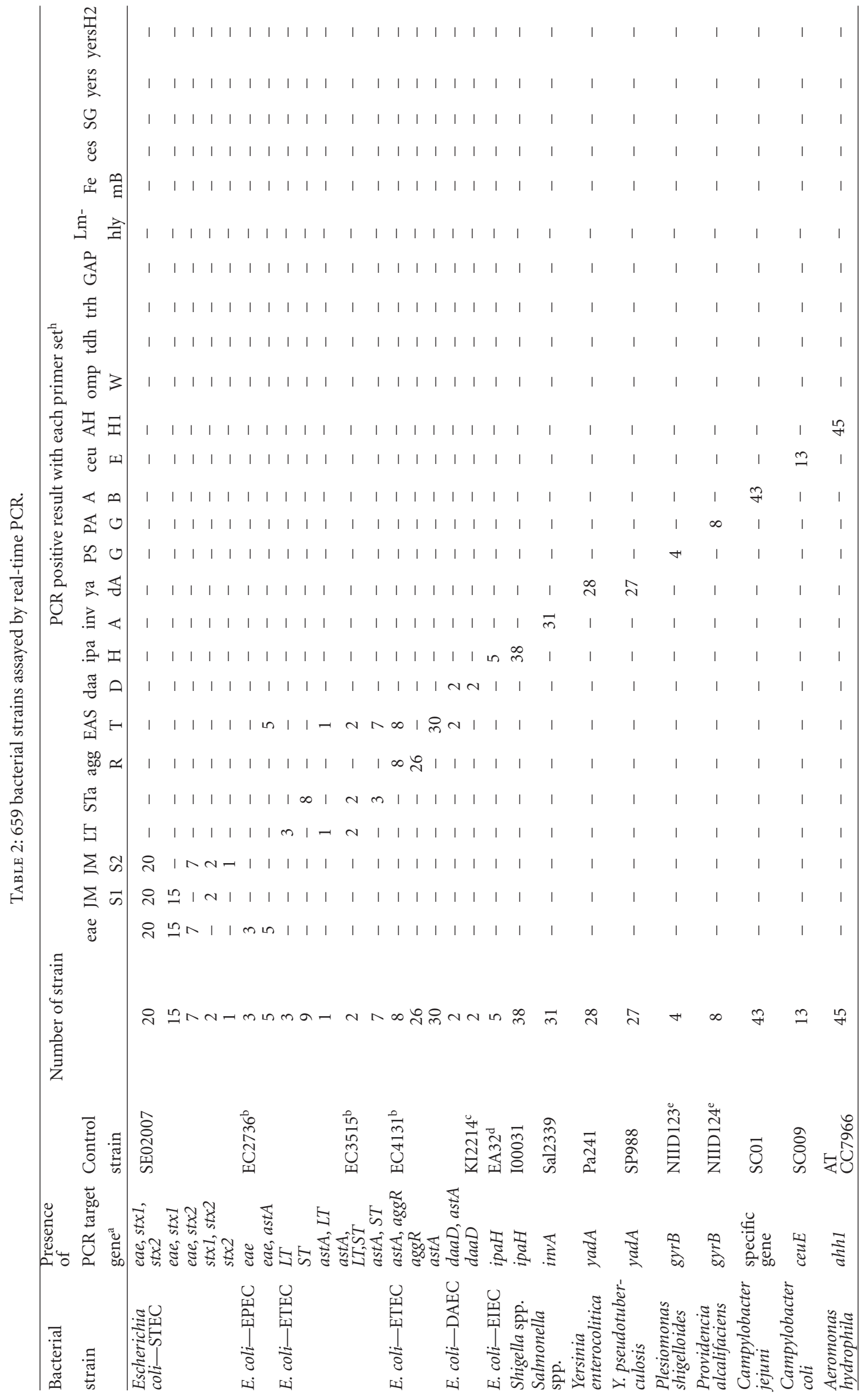




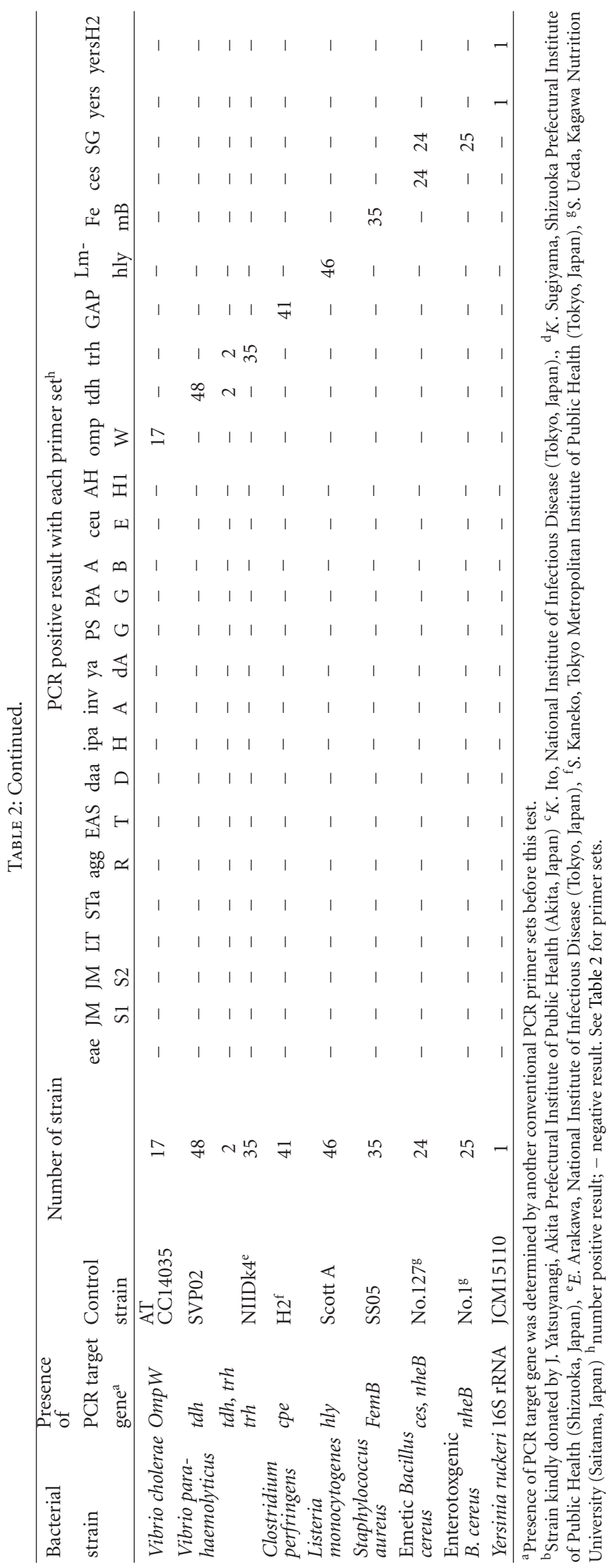


2.5. Real-Time Multiplex SG-PCR. Real-time multiplex SGPCR and data analysis were performed for a total volume of $20 \mu \mathrm{L}$ using 96-well reaction plates and an ABI7500 or ABI7500 Fast Real-Time PCR system (Applied Biosystems), LightCycler 480 (Roche) or Thermal Cycler Dice Real-Time System (Takara, Japan). Each reaction tube contained $10 \mu \mathrm{L}$ of SYBR Premix DimerEraser (Takara, Japan), $0.4 \mu \mathrm{L}$ of ROX Reference Dye II (50×) (for ABI 7500 and ABI7500 Fast), $0.8 \mu \mathrm{L}$ (for $\mathrm{ABI} 7500$ and $\mathrm{ABI} 7500$ Fast), or $1.2 \mu \mathrm{L}$ (for LightCycler 480 and Thermal Cycler Dice) of PCR-grade $\mathrm{H}_{2} \mathrm{O}$, each $1.2 \mu \mathrm{L}$ of a $10 \mu \mathrm{M}$ primer set for 3 target genes, $1.2 \mu \mathrm{L}$ of a $10 \mu \mathrm{M}$ IAC primer set, $2 \mu \mathrm{L}$ of IAC DNA, and $2 \mu \mathrm{L}$ of sample DNA in a $20 \mu \mathrm{L}$ PCR mixture. In each of 8 lines (12 wells per line) on a 96-well reaction plate, the samples were set as negative control $\left(4 \mu \mathrm{L}\right.$ of $\left.\mathrm{dH}_{2} \mathrm{O}\right)$ in the 1st well, each $2 \mu \mathrm{L}$ of IAC, and $\mathrm{dH}_{2} \mathrm{O}$ in the 2 nd well, each $2 \mu \mathrm{L}$ of IAC, and 1 out of 3 target positive controls in the 3 rd to 5 th wells, and $2 \mu \mathrm{L}$ of IAC and each 7 stool DNA samples in the 6th to 12th wells. The PCR amplicons resulting from foodborne pathogens and Y. ruckeri were used for the positive controls and IAC, respectively. The concentrations of positive control (equal $10^{5}$ to $10^{6} \mathrm{cfu} / \mathrm{g}$ ) were adjusted to become the $C_{t}$ values to 17 to 21 by dilution of $10^{3}$ - to $10^{4}$-fold with Easy Dilution (Takara, Japan) and two IACs (equal $10^{1}$ to $10^{2} \mathrm{cfu} / \mathrm{g}$ ) were adjusted to become the $C_{t}$ values to 27 to 29 by dilution of $10^{6}$ - to $10^{7}$-fold with Easy Dilution. The assay cycling profile was one cycle of $95^{\circ} \mathrm{C}$ for $30 \mathrm{~s}$ followed by 30 cycles of denaturation at $95^{\circ} \mathrm{C}$ for $5 \mathrm{~s}(3 \mathrm{~s}$ for $\mathrm{ABI} 7500$ Fast), annealing at $55^{\circ} \mathrm{C}$ for $30 \mathrm{~s}$ ( $34 \mathrm{~s}$ for $\mathrm{ABI}$ 7500 ) and then $72^{\circ} \mathrm{C}$ for $30 \mathrm{~s}$ ( $34 \mathrm{~s}$ for $\mathrm{ABI} 7500$ ), and a dissociation stage of 1 cycle at $95^{\circ} \mathrm{C}$ for $15 \mathrm{~s}, 60^{\circ} \mathrm{C}$ for $60 \mathrm{~s}$, and $95^{\circ} \mathrm{C}$ for $15 \mathrm{~s}$. The specificity of the reaction was found by the detection of the Tms of the amplification products immediately after the last reaction cycle. These reactions were finished in 2 hours or less. Results were analyzed with SDS software provided with each real-time PCR system.

2.6. Multiplex Real-Time SG-PCR Analysis in 35 Foodborne Outbreaks. Multiplex real-time SG-PCR analysis of foodborne outbreak was experimentally tested using the ABI 7500 in Shimane (22 cases between 2002 and 2009), Fukuoka ( 3 cases between 2006 and 2009), and Shizuoka Prefecture 3 cases on 2009), using ABI 7500 Fast in Fukuoka Prefecture ( 2 cases on 2009), using Thermal Cycler Dice Real Time System in Hokkaido (3 cases between 2008 and 2009), and using LightCycler 480 in Kumamoto Prefecture (2 cases on 2009) (Table 3). The DNA samples were extracted with the QIAamp DNA Stool Mini kit from patient fecal samples (within 1 hour) and were set on a 96-well reaction plate as described above. The samples before 2008 were used after 1 to 3 years store at $-20^{\circ} \mathrm{C}$. The multiplex PCR assay was evaluated with regard to detection (in 2 hours or less) of 24 specific genes of foodborne pathogens in 7 stool specimens. Each PCR product was generated with a different Tm curve among $4 \mathrm{Tm}$ curves of PCR target gene products. These could all be resolved using each software and Tm curve analysis whenever target bacteria were present in the reaction well.

\section{Results and Discussion}

3.1. Noncompetitive IAC and Two IAC Primers. In this study, the Y. ruckeri bacterium was successfully used as a noncompetitive IAC and for 2 pairs of IAC primer for routine detection of 24 target genes of foodborne pathogens. Using an IAC with real-time PCR detection is important to identify false negative results and to control for the presence of amplification inhibitors [26]. It is important to take into account that components of the sample or the competing microflora may influence the effectiveness of the PCR, especially by reducing the detection limit and producing false negative results. The consequences of false negative results in the detection of a pathogenic microorganism may potentially be life threatening [27]. The European Standardization Committee, in collaboration with International Standard Organization (ISO), has proposed a general guideline for PCR testing of foodborne pathogens that requires presence of IAC in the reaction mixture [28].

While some design approaches such as cloning require substantial technical skills, others can be done using basic PCR methodology. There are two main strategies for use of an IAC in a diagnostic real-time PCR assay. Their difference lies in whether the IAC is to be used competitively or noncompetitively [5]. By using the composite primer technique, the target and the competitive IAC are amplified with one common set of primers and under the same conditions and in the same real-time PCR tube. The competitive IAC method was used for TaqMan PCR to detect $S$. enterica [26, 29, 30], E. coli O157 [31], and C. botulinum [32] and real-time SG-PCR to detect C. botulinum [33]. However, these competitive IAC methods can lower the amplification efficiency, which results in a lower detection limit [5]. In the noncompetitive IAC method, the target and IAC are amplified using a different primer set for each. The disadvantage is that amplification of the IAC may not accurately reflect amplification of the target. This method was used for TaqMan PCR to detect Campylobacter spp. [9, 34], B. cereus [35], C. botulinum [36], and V. parahaemolyticus [7]. These assays were used for the detection of single target gene except for the four-target TaqMan multiplex PCR to detect $V$. parahaemolyticus [7]. Although the main advantage of the noncompetitive IAC method is that it can be used for many different assays in the same laboratory [5], we do not have a unique real-time PCR assay for the detection of almost all foodborne pathogens using universal IAC.

Each previously described method for introduction of an IAC is limited due to primer competition or because it requires the presence of a specific substrate or organism. The new approach presented in this paper comprises a separate amplification of target DNA and noncompetitive IAC-DNA using each specific target primer set and two different IAC primer sets on the detection of each foodborne pathogens. The latter is based on $16 \mathrm{~S}$ rRNA of Y. ruckeri, which is not found naturally in human stool and food samples.

The IAC primer yers $\mathrm{H} 2$ was used for detection of 15 target genes of foodborne pathogens which $\mathrm{Tm}$ values of amplicons were lower than $83^{\circ} \mathrm{C}$ and shown as primer sets A to $\mathrm{E}$ (described in the next section), and the IAC primer 


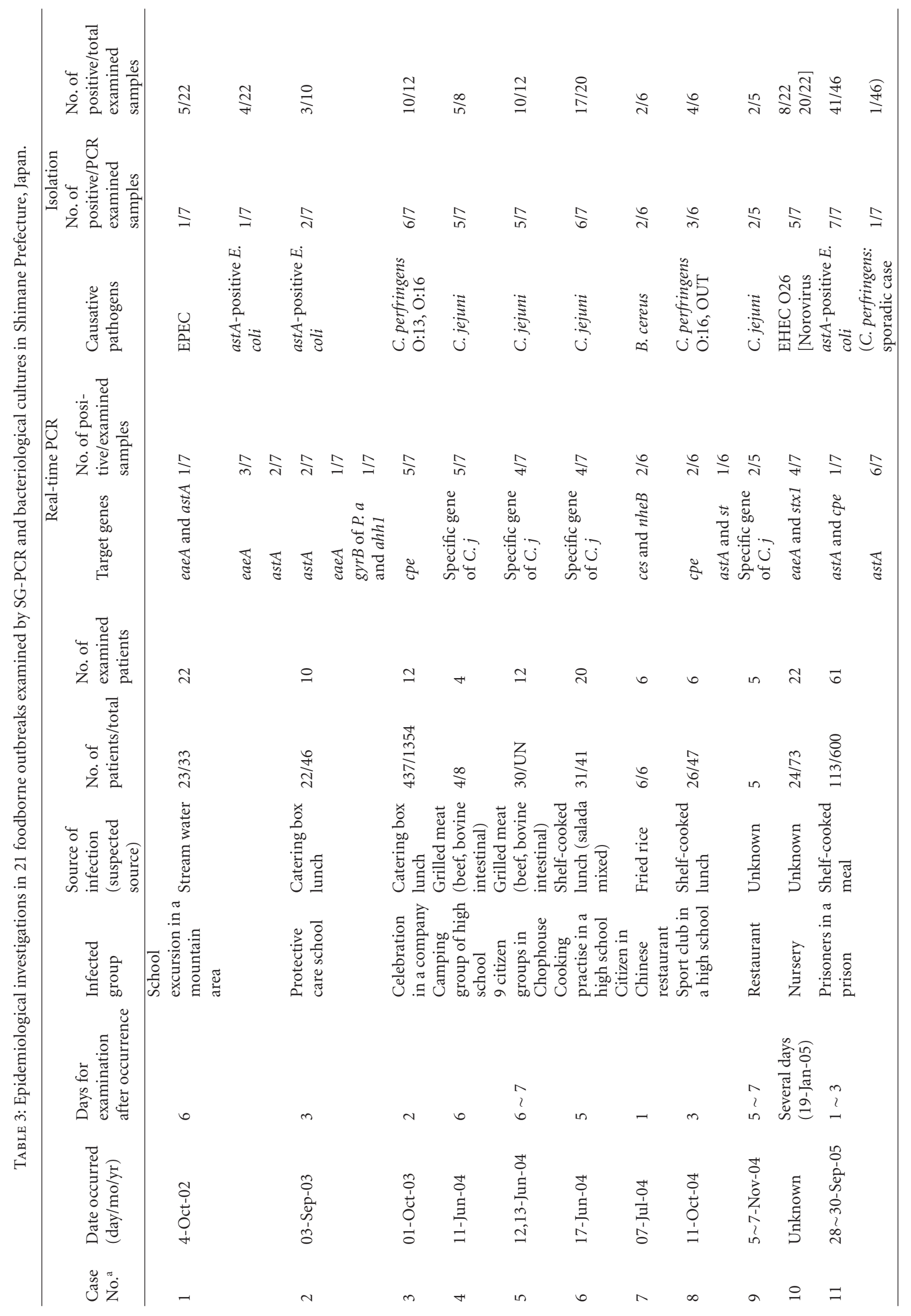




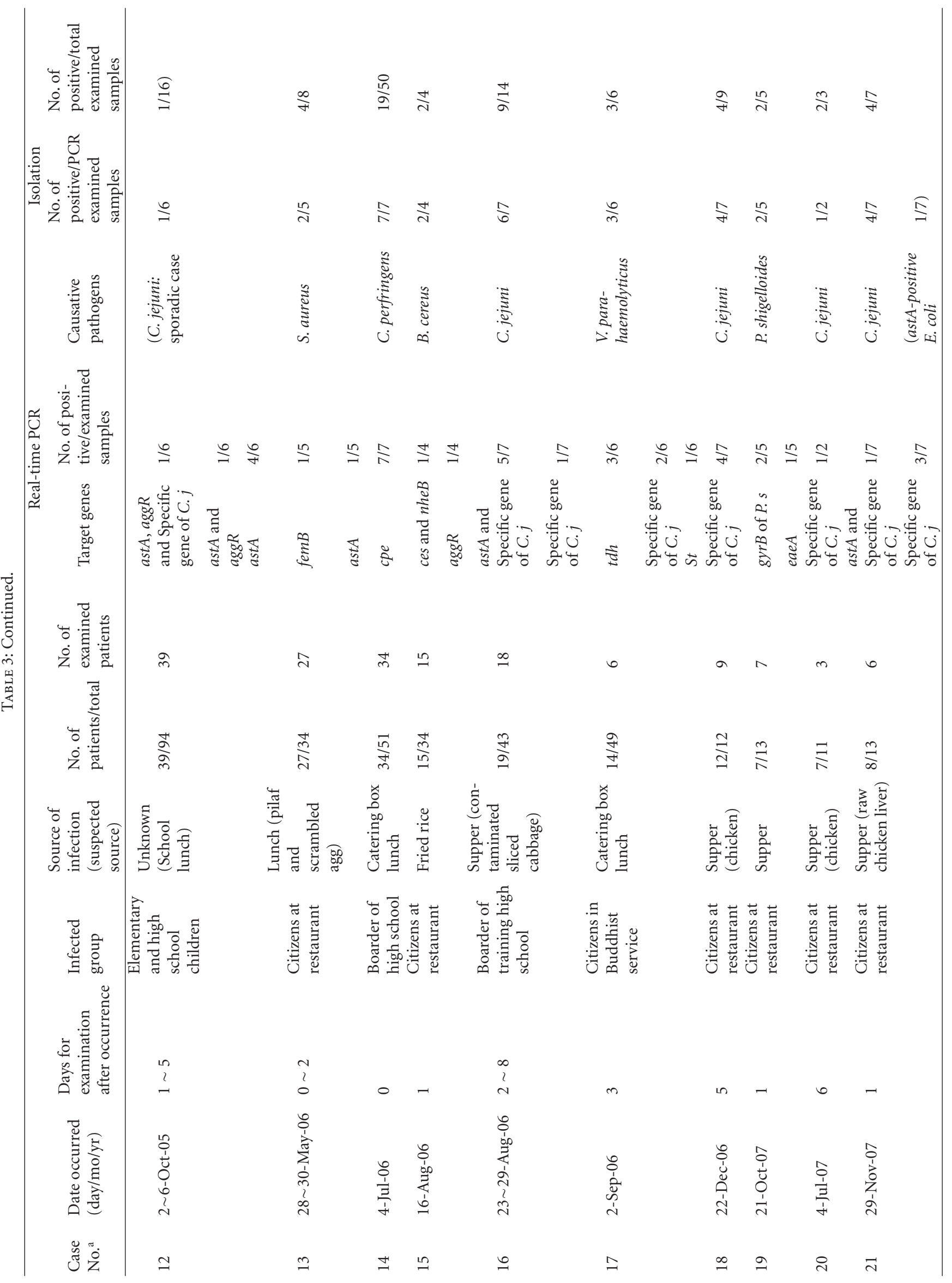




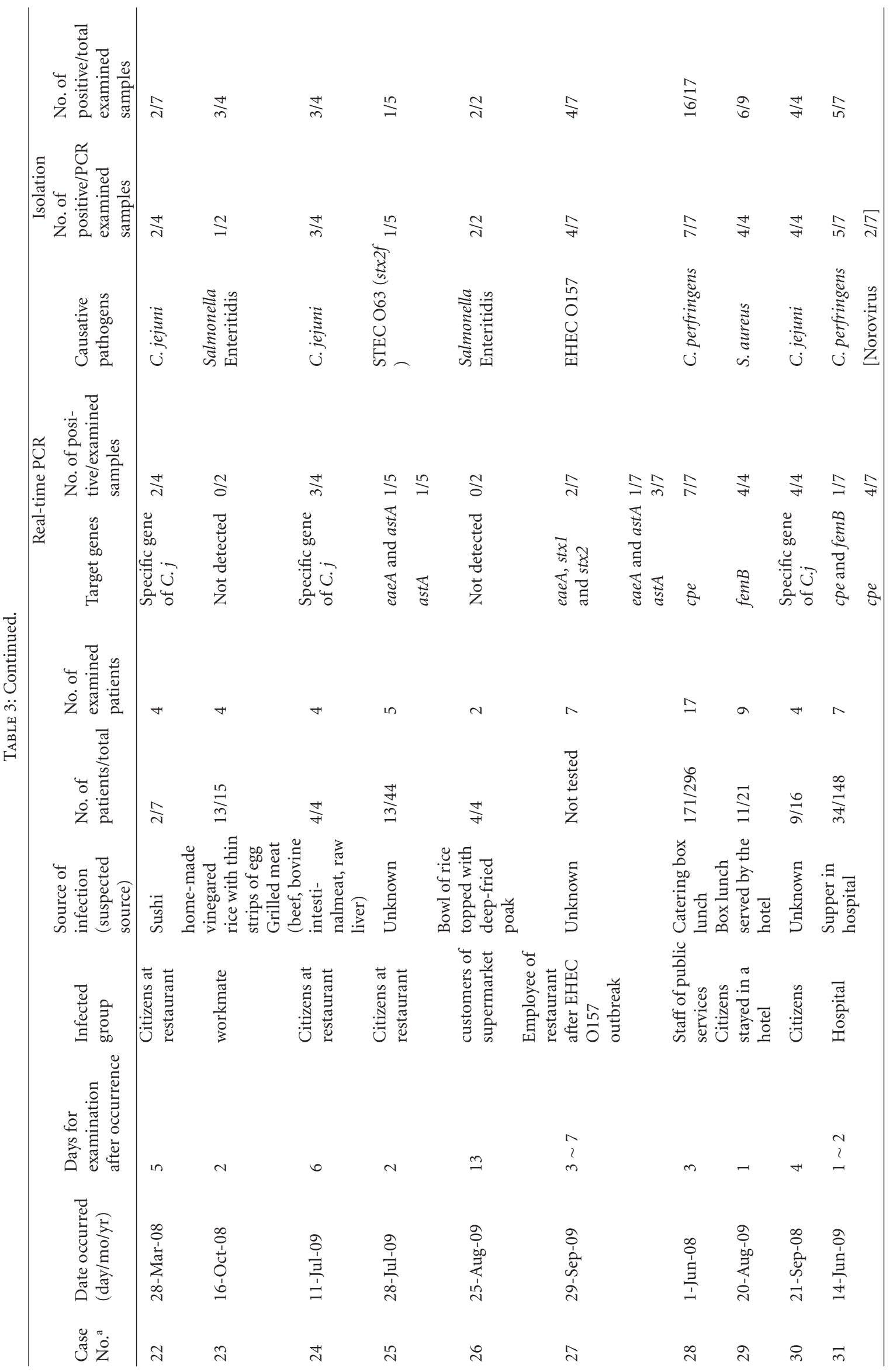




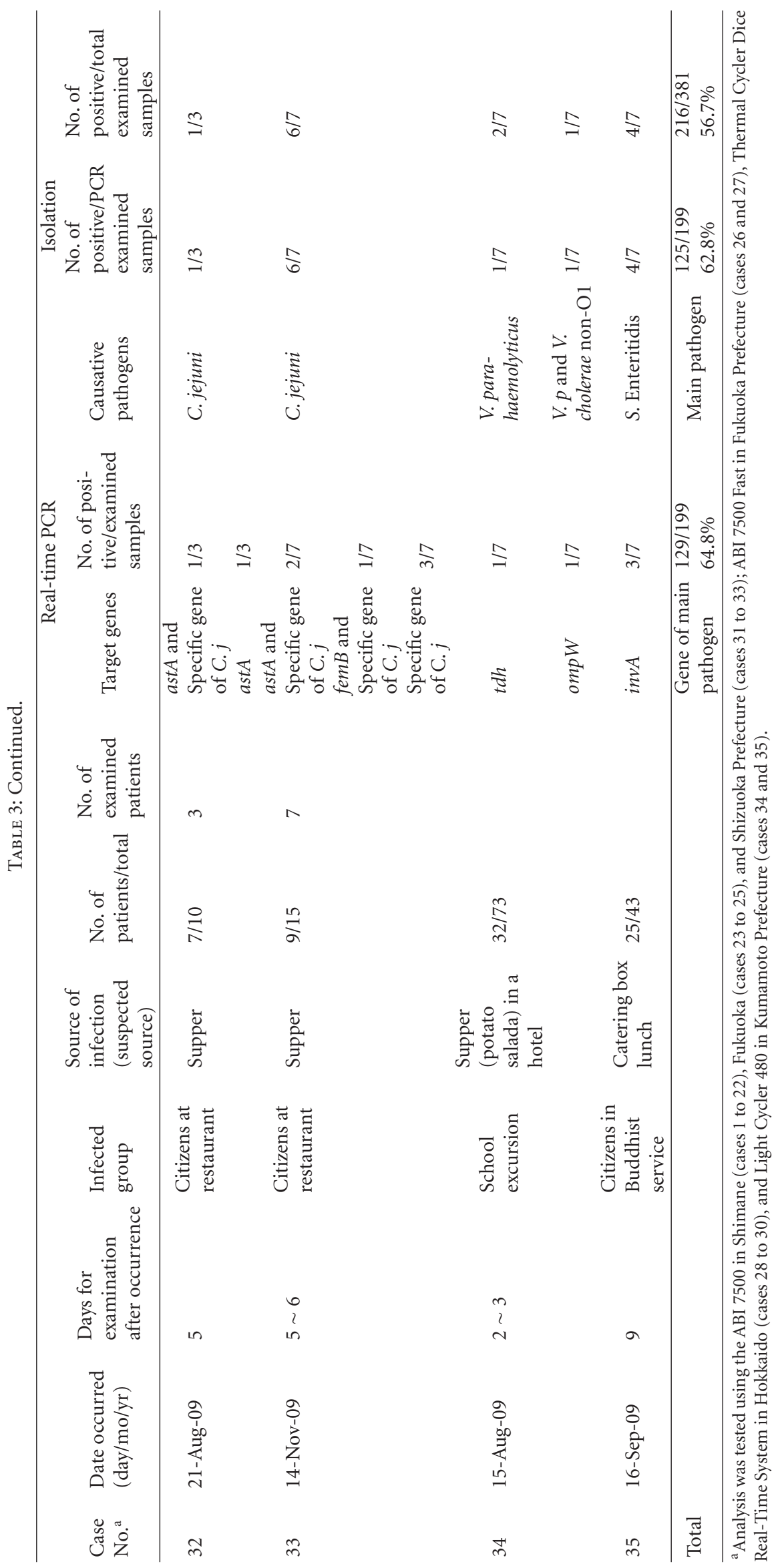


TABLE 4: The relationship between PCR detection and CFU in 15 foodborne outbreak cases by viable cell counting.

\begin{tabular}{|c|c|c|c|c|c|c|c|c|c|c|c|c|c|c|c|c|}
\hline \multirow{4}{*}{ Case } & \multirow{4}{*}{$\begin{array}{l}\text { Causative foodborne } \\
\text { pathogens }\end{array}$} & \multirow{2}{*}{\multicolumn{6}{|c|}{$\begin{array}{l}\text { Multiplex SG-PCR negative samples } \\
\text { Number of samples }\end{array}$}} & \multirow{2}{*}{\multicolumn{9}{|c|}{$\begin{array}{l}\text { Multiplex SG-PCR positive samples } \\
\text { Number of samples }\end{array}$}} \\
\hline & & & & & & & & & & & & & & & & \\
\hline & & \multirow[t]{2}{*}{ Total } & \multicolumn{5}{|c|}{$\log 10 \mathrm{cfu} / \mathrm{g}$ by viable cell counting } & \multirow[t]{2}{*}{ Total } & \multicolumn{8}{|c|}{ Log $10 \mathrm{cfu} / \mathrm{g}$ by viable cell counting } \\
\hline & & & 0 & 2 & 3 & 4 & 5 & & 0 & 2 & 3 & 4 & 5 & 6 & 7 & 8 \\
\hline 3 & C. perfringens & 2 & 2 & & & & & 5 & & & & & 1 & 3 & & 1 \\
\hline 6 & C. jejuni & 3 & 2 & & 1 & & & 4 & & & & 1 & 3 & & & \\
\hline 8 & C. perfringens & 4 & 2 & & 1 & 1 & & 2 & & & & 1 & 1 & & & \\
\hline 9 & C. jejuni & 3 & 3 & & & & & 2 & & & & 2 & & & & \\
\hline 10 & EHEC O26 & 3 & 2 & & 1 & & & 4 & & & 1 & & & 1 & 1 & 1 \\
\hline 11 & ast A-positive E. coli & 0 & & & & & & 7 & & & & & & 1 & & 6 \\
\hline 13 & S. aureus & 4 & 3 & & & 1 & & 1 & & & & 1 & & & & \\
\hline 14 & C. perfringens & 0 & & & & & & 7 & & & & & 1 & 3 & 3 & \\
\hline 17 & B. cereus & 3 & 3 & & & & & 1 & & & & 1 & & & & \\
\hline 18 & C. jejuni & 1 & & & & & 1 & 5 & & & & & 1 & & 2 & 2 \\
\hline 20 & C. jejuni & 3 & 3 & & & & & 4 & & & 1 & & 3 & & & \\
\hline \multirow[t]{2}{*}{19} & P. shigelloides & 3 & 3 & & & & & 2 & & & & & 2 & & & \\
\hline & astA-positive E. coli & 4 & 4 & & & & & 1 & & & & 1 & & & & \\
\hline 21 & C. jejuni & 3 & 3 & & & & & 4 & & & & & 3 & 1 & & \\
\hline 26 & S. enterica serovar Enteritidis & 2 & & & & 2 & & 0 & & & & & & & & \\
\hline \multirow[t]{2}{*}{27} & EHEC O157 & 5 & 5 & & & & & 2 & & 1 & 1 & & & & & \\
\hline & Total & 43 & 35 & 0 & 3 & 4 & 1 & 51 & 0 & 1 & 3 & 7 & 15 & 9 & 6 & 10 \\
\hline
\end{tabular}

yers was used for detection of 9 target genes of foodborne pathogens which $\mathrm{Tm}$ values of amplicons were over than $80^{\circ} \mathrm{C}$ and shown as primer sets $\mathrm{F}$ to $\mathrm{H}$ (described in the next section). The IAC-specific low peak on a $\mathrm{Tm}$ curve analysis was present in all reaction tubes added with IAC and IAC primers and in all the negative results of target PCR in reaction tubes added with IAC primers (Figures 1 and 2).

3.2. Development of PCR Procedures for a Set of 8 Multiplex Assays. We developed the ultimately new PCR screening system for foodborne pathogens in stool specimens. One can simultaneously analyze 24 pathogenic or specific genes of foodborne pathogens in 7 stool specimens by using multiplex real-time SG-PCR containing IAC and 96-well reaction plate. Single or multiple real-time PCR assays were reported for detection of one species among foodborne pathogens, such as E. coli [11, 17, 18, 22], Salmonella [26, 28, 29], C. jejuni [13, 37], V. cholerae [19], V. parahaemolyticus [38], and S. aureus [21]. Comprehensive, rapid real-time SG-PCR procedures, which used 24 primer pairs for detection of 15 bacterial species including: 6 groups of $E$. coli, 2 subgroups each of B. cereus and V. parahaemolyticus, and 2 primer pairs for an IAC, were developed using a set of 8 multiplex PCR assays with 3 primer pairs for foodborne pathogens and an IAC primer pair. Nineteen pairs of primers for foodborne pathogens were selected from earlier publications (Table 1), and 5 pairs of primers for $t d h$ gene of TDHpositive $V$. parahaemolyticus, yadA gene of $Y$. enterocolitica and Y. pseudotuberculosis, gyrB gene of P. shigelloides, ipaH gene of EIEC and Shigella spp., and daaD gene of DAEC were constructed. This was done to make all 24 SG-PCR methods suitable for the same PCR conditions (an annealing temperature of $\left.60^{\circ} \mathrm{C}\right)$. The sequence, target, PCR product size, threshold cycle $\left(C_{t}\right)$ values, and $T m$ values of 24 primer pairs for target genes and 2 primer pairs for IAC are listed in Table 1. The specificity of the PCR assay was confirmed on 659 strains listed in Table 2. The STa-F and STa-R primer pair could not detect st gene from 5 of 18 st-positive ETEC strains. The ipaH1672-F and ipaH1761-R primer pair crossreacts with Shigella spp. and EIEC. The SG-F and SG-R primer pair cross-reacts with enterotoxigenic and emetic B. cereus. As same as previous studies [4], the eae-F2 and eae-R primer pair cross-reacts with EPEC and EHEC, and the EAST-1S and EAST-1AS primer pair cross-reacts with EAEC and some strains of EPEC, ETEC, and DAEC. The yadA667-F and yadA851-R2 for Yersinia adhesion reacts with virulent $Y$. enterocolitica and Y. pseudotuberculosis, but not with nonpathogenic strains of Yersinia spp.

A Foodborne Outbreak Investigation Report (http:// www.mhlw.go.jp/topics/syokuchu/), by the Ministry of Health, Labor and Welfare, Japan, during 2005 to 2008, shows that $97 \%$ of foodborne outbreaks were caused by the following 7 species of foodborne pathogens: $C$. jejuni (56.5\%), S. enterica (16.0\%), TDH-positive V. parahaemolyticus (10.0\%), S. aureus $(6.8 \%)$, C. perfringens $(3.4 \%)$, emetic B. cereus $(2.0 \%)$, and EHEC $(2.4 \%)$, and other virulent $E$. coli $(2.1 \%)$ which include astA-positive $E$. coli which is a strain of $E$. coli that does not possess any diarrheagenic characteristics except the EAEC heatstable toxin 1 (EAST1) gene and is frequently isolated in diarrhea outbreaks [39]. Each primer set was combined with 4 primer pairs designed for 1 of 8 main foodborne pathogens and were also designed for IAC and 2 of 16 target genes of other foodborne pathogens (Table 2). Particularly each 


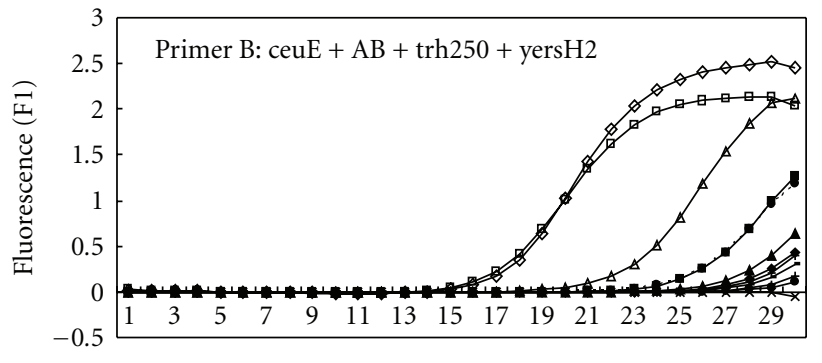

Cycle number

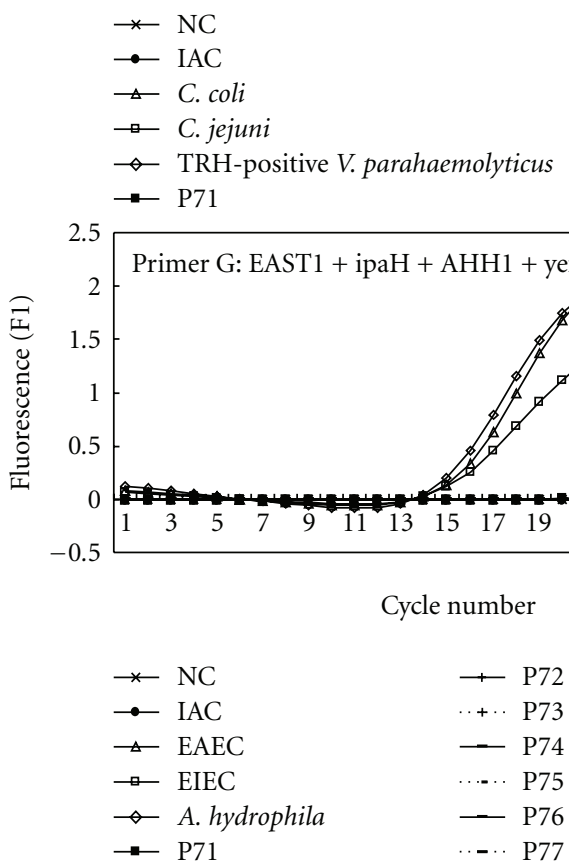

(a)

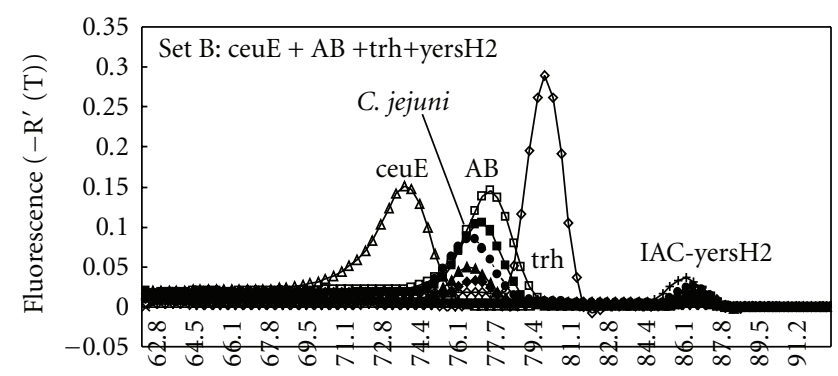

Temperature $\left({ }^{\circ} \mathrm{C}\right)$
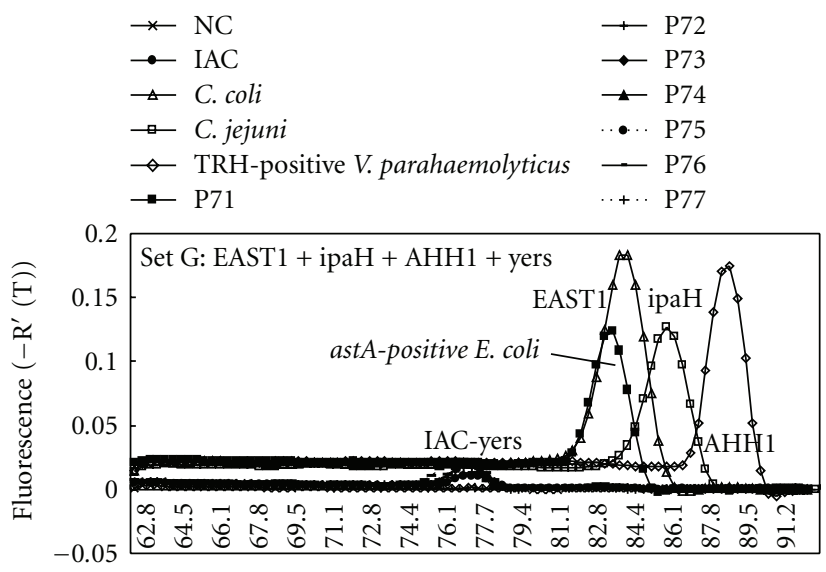

Temperature $\left({ }^{\circ} \mathrm{C}\right)$

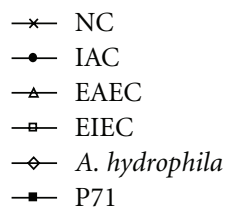

(b)

FIGURe 2: Melting curve analysis of multiplex real-time SG-PCR products from 7 stool samples in case 21 of a foodborne outbreak. Two panels show detection of target genes of foodborne pathogens by primer sets B and G, but it was not detected by the other 6 primer sets.

primer for 8 main foodborne pathogens was carefully set in 8 different primer sets for keeping away from the presence of multiple primers for main foodborne pathogens in the same reaction well. Really the plural target genes were detected from 26 stool samples in 15 cases of foodborne outbreaks but these target genes were, respectively, detected from different reaction wells (Table 3 ). The fluorescent amplification curves and Tm curves of the multiplex SG-PCR products of the DNA of foodborne pathogens and IAC were shown in Figure 1. The $C_{t}$ values of the amplicons resulting from foodborne pathogens were 17 to 21 and those of IAC were 27 to 29 . In each analysis, the $T_{m}$ distance was from 0.8 to $6.2^{\circ} \mathrm{C}$ among the target gene's products. Looking at the short variations among some $T_{m}$ distance in set $\mathrm{C}$ and set $\mathrm{E}$, the presence of ces gene in set $C$ could be decided altogether with the presence of nheB gene of $B$. cereus in set $H$ and the presence of st $x 1$ gene in set E could be decided altogether with the presence of eaeA gene of EHEC in set D. The IAC-specific low peak was present in all samples with added IAC $\left(\mathrm{C}_{t}: 27\right.$ to 29) using real-time SG-PCR analysis of the 24 target genes of primer sets A to E including primer yers $\mathrm{H} 2$ and of primer sets $\mathrm{F}, \mathrm{G}$, and $\mathrm{H}$ including primer yers. IAC was certainly amplified in the IAC-only samples. These could be resolved in the ABI 7500 by using Tm curve analysis when a target bacterium was present in the reaction tube. The $T m$ values of PCR products of stool samples, including each foodborne pathogens, could be identified with that of control bacteria in the same run based on a Tm curve analysis.

3.3. Multiplex SG-PCR for Identification of the Causative Pathogens in Foodborne Outbreaks. In foodborne outbreaks, stool specimens from patients infected with enteric bacteria with acute severe disease may contain large numbers of causative bacterial species $[2,11]$. In most cases of foodborne outbreak, we found that causative bacteria can be rapidly detected and that a presumptive diagnosis of the causative agent of foodborne outbreak could be made within 3 hours. We used a combination of the multiplex real-time SG-PCR assay with DNA extraction with the QIAamp DNA Stool 
Mini kit used for detection. Almost all bacterial pathogens are detectable in stool specimens at a concentration of $10^{3}$ to $10^{4}$ bacteria per $\mathrm{g}$. This is because the concentration of DNA extracted from stool specimens using this DNA extraction kit was finally diluted to $6 \times 10^{4}$-fold in the reaction mixture. The PCR sensitivity for bacteria inoculated in stool samples may be as low as the presence of 10 cells in the reaction well, as described in our previous report [2]. The real-time SG-PCR assay is a rapid, specific, and sensitive detection technique. The DNA extraction of 7 stool specimens with this DNA extraction kit was carried out within 1 hour. Then, the multiplex real-time SG-PCR assay was also carried out within 2 hours, and we could then specifically identify the products based on a Tm curve analysis. For example, Figure 2 shows those of case 21, in which C. jejuni and astApositive E. coli strains were isolated from 4 and one of 7 stool specimens of symptomatic patients, respectively. Two panels show detection of target genes of foodborne pathogens by primer sets B and G, but it was not detected by the other 6 primer sets. In multiplex PCR analysis, the $C$. jejuni-specific gene and the astA gene were simultaneously detected by primer sets B and $G$ from the same culture-positive stool specimens.

3.4. Identification of the Causative Pathogens in 35 Foodborne Outbreaks using Multiplex SG-PCR. Table 3 shows epidemiological and clinical investigations in 35 foodborne outbreaks (occurred between 2002 and 2009) examined by multiplex SG-PCR analysis in 5 different laboratories in 2009. DNA samples extracted from 2 to 7 feces of symptomatic patients were stored at $-20^{\circ} \mathrm{C}$ until using. In $33(94.3 \%)$ of 35 foodborne outbreak cases, the causative bacteria and/or some sporadic bacteria were comprehensive and simultaneously detected using multiplex SG-PCR from stool specimens. Moreover, the same reactions, which IACspecific low peak was present in reaction tubes added with IAC and IAC primer yers $\mathrm{H} 2$ or yers, were observed. This demonstrated the absence of PCR inhibitor in DNA specimens extracted from patient stool specimens using this DNA extraction kit. In this study, it was confirmed that using IAC and 2 IAC primers with different $T m$ values was advantageous to allow elimination of false negative results in real-time SG-PCR for the detection of 24 target genes of foodborne pathogens. The results of multiplex real-time SGPCR assay of 7 foodborne outbreaks were confirmed by the use of IAC and 2 IAC primers. The certain amplification of target genes and IAC in each multiplex PCR analysis demonstrated the usefulness of this multiplex real-time SGPCR as reliable diagnostic PCR.

The target genes of 12 species of foodborne bacteria (C. jejuni, E. coli, C. perfringens, S. aureus, Salmonella spp., V. parahaemolyticus, V. cholerae non-O1, B. cereus, $P$. alcalifaciens, $P$. shigelloides, and $A$. hydrophila), which included 5 groups of E. coli (EHEC, EPEC, EAEC, ETEC, and astA-positive E. coli), were detected from $129(64.8 \%)$ of 199 feces in $33(94.3 \%)$ of 35 cases by multiplex SGPCR, from 1 to 7 samples. Multiplex SG-PCR rapidly and accurately demonstrated that $11(31.4 \%)$ of 35 cases were caused with a single foodborne pathogen such as $C$. jejuni
(7 cases), C. perfringens (2 cases), B. cereus (1 case), and $S$. Enteritidis (1 case). There were also 19 (54.2\%) cases with plural foodborne bacterial pathogens and $3(2.9 \%)$ cases with foodborne bacterial pathogens (astA-positive E. coli, EHEC O:26, or C. perfringens) and norovirus. The causative pathogens had been isolated from 125 (62.8\%) of 199 PCR examined samples and from $216(56.7 \%)$ of 381 total samples in all 35 cases. Although the target genes of EPEC, EAEC, ETEC, astA-positive E. coli, P. alcalifaciens, and A. hydrophila were detected by SG-PCR, the isolation of these pathogens from the stool samples containing much normal E. coli flora was difficult. This analysis may be a very useful tool for the detection of these unusual pathogens which are generally difficult to isolate. We previously reported that the presence of any foodborne pathogens at more than $10^{3} \mathrm{CFU} / \mathrm{g}$ feces was certainly confirmed by melting curve analysis in duplex SG-PCR $[2,4]$. In this multiplex PCR analysis including IAC, the presence of any foodborne pathogens at more than $10^{5} \mathrm{CFU} / \mathrm{g}$ feces was certainly confirmed in $40(97.6 \%)$ of 41 samples by melting curve analysis, $10^{4} \mathrm{CFU} / \mathrm{g}$ feces was confirmed in $7(63.6 \%)$ of 11 samples and $10^{3} \mathrm{CFU} / \mathrm{g}$ feces in $3(50 \%)$ of 6 samples (Table 4$)$. The sensitivity of this multiplex SG-PCR including IAC might became slightly lower than that of duplex SG-PCR (absent IAC), caused by the interference among 4 primer pairs including IAC primer in the same reaction well. In 2 cases $(5.7 \%)$, in which S. enteric serovar Enteritidis was isolated by direct culture (unknown cfu) from one patient in case 23 and $10^{4} \mathrm{cfu} / \mathrm{g}$ of feces from 2 patients in case 26 , the target gene of Salmonella was not detected by multiplex SG-PCR, because the sensitivity of invA2 primer may be slightly lower than those of other primers. The choice or design of more sensitive primer for the detection of Salmonella spp. is indispensable in future studies.

3.5. Usefulness of Multiplex SG-PCR for the Rapid Diagnostic Test in Foodborne Outbreaks. Systematically reviewing clinical implications, public health considerations, and costeffectiveness of rapid diagnostic tests for detection and identification of bacterial intestinal pathogens in feces and food [1], economic modeling suggests that adoption of rapid test methods, especially for PCR, in combination with a routine culture is unlikely to be cost-effective, however, as the cost of rapid technologies decreases, total replacement with rapid technologies may be feasible. Despite the relatively poor quality of reporting of studies evaluating rapid detection methods, the reviewed evidence shows that PCR for Campylobacter, Salmonella, and E. coli O157 is potentially very successful in identifying pathogens. It is possibly detecting more than the numbers currently being reported using cultures. Less is known about the benefits of testing for $B$. cereus, $C$. perfringens, and $S$. aureus. This review pointed out that further investigation is needed on how clinical outcomes may be altered if test results are available more quickly and at greater precision than the current practice of using bacterial culture [1]. In the present study, simple and specific methods were established to detect comprehensive and simultaneously 24 specific genes of foodborne pathogens including main bacterial pathogens 
such as Campylobacter, Salmonella, E. coli O157, B. cereus, C. perfringens, and S. aureus in 7 stool specimens in a real-time SG-PCR assay using a 96-well reaction plate containing a universal noncompetitive IAC. The usefulness of this method for the rapid diagnostic tests was confirmed by the successful detection of causative bacteria in 33 foodborne outbreak cases.

In conclusion, the multiplex real-time method described here for simultaneous screening of 24 target genes of foodborne pathogens were comprehensive, rapid, inexpensive, highly selective, accurate, and demonstrated detection probability. Due to the use of IAC and 2 IAC primers, the assay is suitable for accurate and rapid diagnosis of almost all foodborne pathogens in stool specimens of foodborne outbreak outbreaks. In future studies, workers should improve the kit of multiplex real-time PCR and select more suitable primers for foodborne pathogens.

\section{Acknowledgments}

We are very thankful to Dr. T. Yoshimura and Dr. T. Nagai for helpful advice to this work. This work was supported in part by a Grant-in-Aid from the Japanese Ministry of Health, Labor, and Welfare (H19-Kenki-011).

\section{References}

[1] I. Abubakar, L. Irvine, C. F. Aldus et al., "A systematic review of the clinical, public health and cost-effectiveness of rapid diagnostic tests for the detection and identification of bacterial intestinal pathogens in faeces and food," Health Technology Assessment, vol. 11, no. 36, pp. 1-216, 2007.

[2] H. Fukushima and Y. Tsunomori, "Study of real-time PCR assays for rapid detection of food-borne pathogens," Kansenshogaku Zasshi, vol. 79, no. 9, pp. 644-655, 2005.

[3] H. Fukushima, Y. Tsunomori, and R. Seki, "Duplex realtime SYBR green PCR assays for detection of 17 species of food- or waterborne pathogens in stools," Journal of Clinical Microbiology, vol. 41, no. 11, pp. 5134-5146, 2003.

[4] H. Fukushima, K. Katsube, Y. Tsunomori, R. Kishi, J. Atsuta, and Y. Akiba, "Comprehensive and rapid real-time PCR analysis of 21 foodborne outbreaks," International Journal of Microbiology, vol. 2009, Article ID 917623, 13 pages, 2009.

[5] J. Hoorfar, B. Malorny, A. Abdulmawjood, N. Cook, M. Wagner, and P. Fach, "Practical considerations in design of internal amplification controls for diagnostic PCR assays," Journal of Clinical Microbiology, vol. 42, no. 5, pp. 1863-1868, 2004.

[6] I. G. Wilson, "Inhibition and facilitation of nucleic acid amplification," Applied and Environmental Microbiology, vol. 63, no. 10, pp. 3741-3751, 1997.

[7] J. L. Nordstrom, M. C. L. Vickery, G. M. Blackstone, S. L. Murray, and A. DePaola, "Development of a multiplex realtime PCR assay with an internal amplification control for the detection of total and pathogenic Vibrio parahaemolyticus bacteria in oysters," Applied and Environmental Microbiology, vol. 73, no. 18, pp. 5840-5847, 2007.

[8] A. Gibello, M. M. Blanco, M. A. Moreno et al., "Development of a PCR assay for detection of Yersinia ruckeri in tissues of inoculated and naturally infected trout," Applied and Environmental Microbiology, vol. 65, no. 1, pp. 346-350, 1999.

[9] M. Lund, S. Nordentoft, K. Pedersen, and M. Madsen, "Detection of Campylobacter spp. in chicken fecal samples by real-time PCR," Journal of Clinical Microbiology, vol. 42, no. 11, pp. 5125-5132, 2004.

[10] N. Kato, S. M. Kim, H. Kato et al., "Identification of enterotoxin-producing Clostridium perfringens by the polymerase chain reaction," The Journal of the Japanese Association for Infectious Diseases, vol. 67, no. 8, pp. 724-729, 1993.

[11] N. Jothikumar and M. W. Griffiths, "Rapid detection of Escherichia coli O157:H7 with multiplex real-time PCR assays," Applied and Environmental Microbiology, vol. 68, no. 6, pp. 3169-3171, 2002.

[12] E. P. Price, F. Huygens, and P. M. Giffard, "Fingerprinting of Campylobacter jejuni by using resolution-optimized binary gene targets derived from comparative genome hybridization studies," Applied and Environmental Microbiology, vol. 72, no. 12, pp. 7793-7803, 2006.

[13] H. K. Nogva, A. Bergh, A. Holck, and K. Rudi, "Application of the $5^{\prime}$-nuclease PCR assay in evaluation and development of methods for quantitative detection of Campylobacter jejuni," Applied and Environmental Microbiology, vol. 66, no. 9, pp. 4029-4036, 2000.

[14] M. Nishibuchi, Y. Takeda, J. Tada et al., "Methods to detect the thermostable direct hemolysin gene and a related hemolysin gene of Vibrio parahaemolyticus by PCR," Nippon Rinsho, vol. 50, supplement, pp. 348-352, 1992 (Japanese).

[15] A. J. Hough, S.-A. Harbison, M. G. Savill, L. D. Melton, and G. Fletcher, "Rapid enumeration of Listeria monocytogenes in artificially contaminated cabbage using real-time polymerase chain reaction," Journal of Food Protection, vol. 65, no. 8, pp. 1329-1332, 2002.

[16] B. Furrer, U. Candrian, and J. Lüthy, "Detection and indentification of E. coli producing heat-labile enterotoxin type I by enzymatic amplification of a specific DNA fragment," Letters in Applied Microbiology, vol. 10, no. 1, pp. 31-34, 1990.

[17] S. M. Franck, B. T. Bosworth, and H. W. Moon, "Multiplex PCR for enterotoxigenic, attaching and effacing, and shiga toxin-producing Escherichia coli strains from calves," Journal of Clinical Microbiology, vol. 36, no. 6, pp. 1795-1797, 1998.

[18] E. M. Nielsen and M. T. Andersen, "Detection and characterization of verocytotoxin-producing Escherichia coli by automated 5' nuclease PCR assay," Journal of Clinical Microbiology, vol. 41, no. 7, pp. 2884-2893, 2003.

[19] A. J. Gubala and D. F. Proll, "Molecular-beacon multiplex realtime PCR assay for detection of Vibrio cholerae," Applied and Environmental Microbiology, vol. 72, no. 9, pp. 6424-6428, 2006.

[20] O. A. Ratchtrachenchai, S. Subpasu, and K. Ito, "Investigation on enteroaggregative Escherichia coli infection by multiplex PCR ," Bulletin of Department Medical Science, vol. 39, pp. 211-222, 1997.

[21] M. Klotz, S. Opper, K. Heeg, and S. Zimmermann, "Detection of Staphylococcus aureus enterotoxins A to D by real-time fluorescence PCR assay," Journal of Clinical Microbiology, vol. 41, no. 10, pp. 4683-4687, 2003.

[22] J. Yatsuyanagi, S. Saito, H. Sato, Y. Miyajima, K.-I. Amano, and K. Enomoto, "Characterization of enteropathogenic and enteroaggregative Escherichia coli isolated from diarrheal outbreaks," Journal of Clinical Microbiology, vol. 40, no. 1, pp. 294-297, 2002. 
[23] G. Wang, C. G. Clark, C. Liu et al., "Detection and characterization of the hemolysin genes in Aeromonas hydrophila and Aeromonas sobria by multiplex PCR," Journal of Clinical Microbiology, vol. 41, no. 3, pp. 1048-1054, 2003.

[24] I.-C. Yang, D. Y.-C. Shih, J.-Y. Wang, and T.-M. Pan, "Development of rapid real-time PCR and most-probable-number real-time PCR assays to quantify enterotoxigenic strains of the species in the Bacillus cereus group," Journal of Food Protection, vol. 70, no. 12, pp. 2774-2781, 2007.

[25] K. Rahn, S. A. De Grandis, R. C. Clarke et al., "Amplification of an invA gene sequence of Salmonella typhimurium by polymerase chain reaction as a specific method of detection of Salmonella," Molecular and Cellular Probes, vol. 6, no. 4, pp. 271-279, 1992.

[26] J. Hoorfar, P. Ahrens, and P. Radstrom, "Automated 5' nuclease PCR assay for identification of Salmonella enterica," Journal of Clinical Microbiology, vol. 38, no. 9, pp. 3429-3435, 2000.

[27] A. Abdulmawjood, S. Roth, and M. Bülte, "Two methods for construction of internal amplification controls for the detection of Escherichia coli $\mathrm{O} 157$ by polymerase chain reaction," Molecular and Cellular Probes, vol. 16, no. 5, pp. 335-339, 2002.

[28] "Microbiology of food and animal feeding stuffs. Polymerase chain reaction (PCR) for the detection of foodborne pathogens," General method specific requirements (EN ISO 22174), International Organization for Standardization, Geneva, Switzerland, 2002.

[29] M. M. Klerks, A. H. C. Van Bruggen, C. Zijlstra, and M. Donnikov, "Comparison of methods of extracting Salmonella enterica serovar enteritidis DNA from environmental substrates and quantification of organisms by using a general internal procedural control," Applied and Environmental Microbiology, vol. 72, no. 6, pp. 3879-3886, 2006.

[30] B. Malorny, E. Paccassoni, P. Fach, C. Bunge, A. Martin, and R. Helmuth, "Diagnostic real-time PCR for detection of Salmonella in food," Applied and Environmental Microbiology, vol. 70, no. 12, pp. 7046-7052, 2004.

[31] M. M. Klerks, C. Zijlstra, and A. H. C. Van Bruggen, "Comparison of real-time PCR methods for detection of Salmonella enterica and Escherichia coli O157:H7, and introduction of a general internal amplification control," Journal of Microbiological Methods, vol. 59, no. 3, pp. 337-349, 2004.

[32] I. Artin, P. Björkman, J. Cronqvist, P. Rådström, and E. Holst, "First case of type E wound botulism diagnosed using realtime PCR," Journal of Clinical Microbiology, vol. 45, no. 11, pp. 3589-3594, 2007.

[33] L. Fenicia, F. Anniballi, D. De Medici, E. Delibato, and P. Aureli, "SYBR green real-time PCR method to detect Clostridium botulinum type A," Applied and Environmental Microbiology, vol. 73, no. 9, pp. 2891-2896, 2007.

[34] M. H. Josefsen, N. R. Jacobsen, and J. Hoorfar, "Enrichment followed by quantitative PCR both for rapid detection and as a tool for quantitative risk assessment of food-borne thermotolerant campylobacters," Applied and Environmental Microbiology, vol. 70, no. 6, pp. 3588-3592, 2004.

[35] M. Fricker, U. Messelhäußer, U. Busch, S. Scherer, and M. Ehling-Schulz, "Diagnostic real-time PCR assays for the detection of emetic Bacillus cereus strains in foods and recent foodborne outbreaks," Applied and Environmental Microbiology, vol. 73, no. 6, pp. 1892-1898, 2007.

[36] D. Akbulut, K. A. Grant, and J. McLauchlin, "Development and application of real-time PCR assays to detect fragments of the Clostridium botulinum types A, B, and E neurotoxin genes for investigation of human foodborne and infant botulism," Foodborne Pathogens and Disease, vol. 1, no. 4, pp. 247-257, 2004.

[37] D. L. Wilson, S. R. Abner, T. C. Newman, L. S. Mansfield, and J. E. Linz, "Identification of ciprofloxacin-resistant Campylobacter jejuni by use of a fluorogenic PCR assay," Journal of Clinical Microbiology, vol. 38, no. 11, pp. 3971-3978, 2000.

[38] L. N. Ward and A. K. Bej, "Detection of Vibrio parahaemolyticus in shellfish by use of multiplexed real-time PCR with TaqMan fluorescent probes," Applied and Environmental Microbiology, vol. 72, no. 3, pp. 2031-2042, 2006.

[39] Y. Nishikawa, J. Ogasawara, A. Helander, and K. Haruki, "An outbreak of gastroenteritis in Japan due to Escherichia coli O166," Emerging Infectious Diseases, vol. 5, no. 2, p. 300, 1999. 

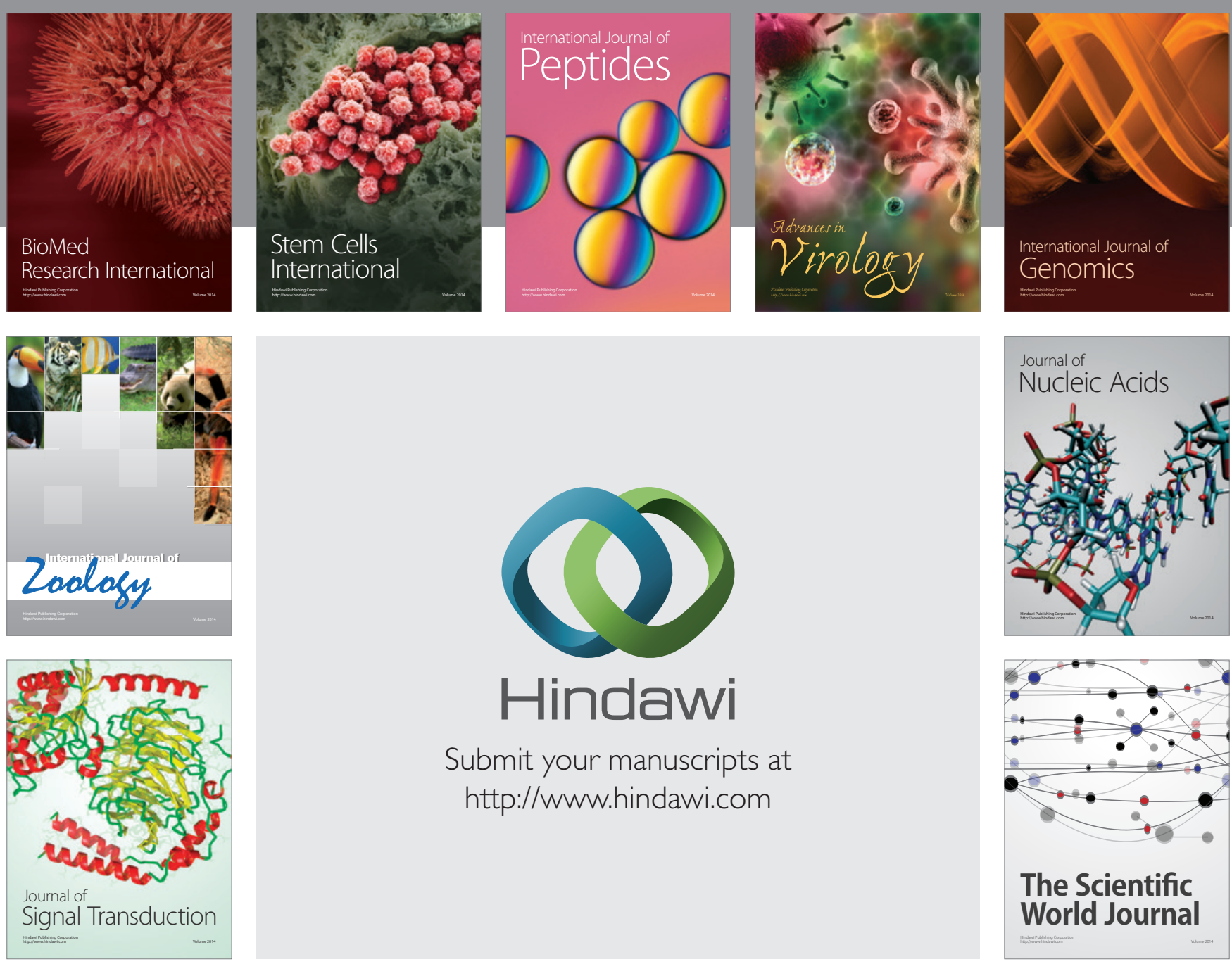

Submit your manuscripts at

http://www.hindawi.com
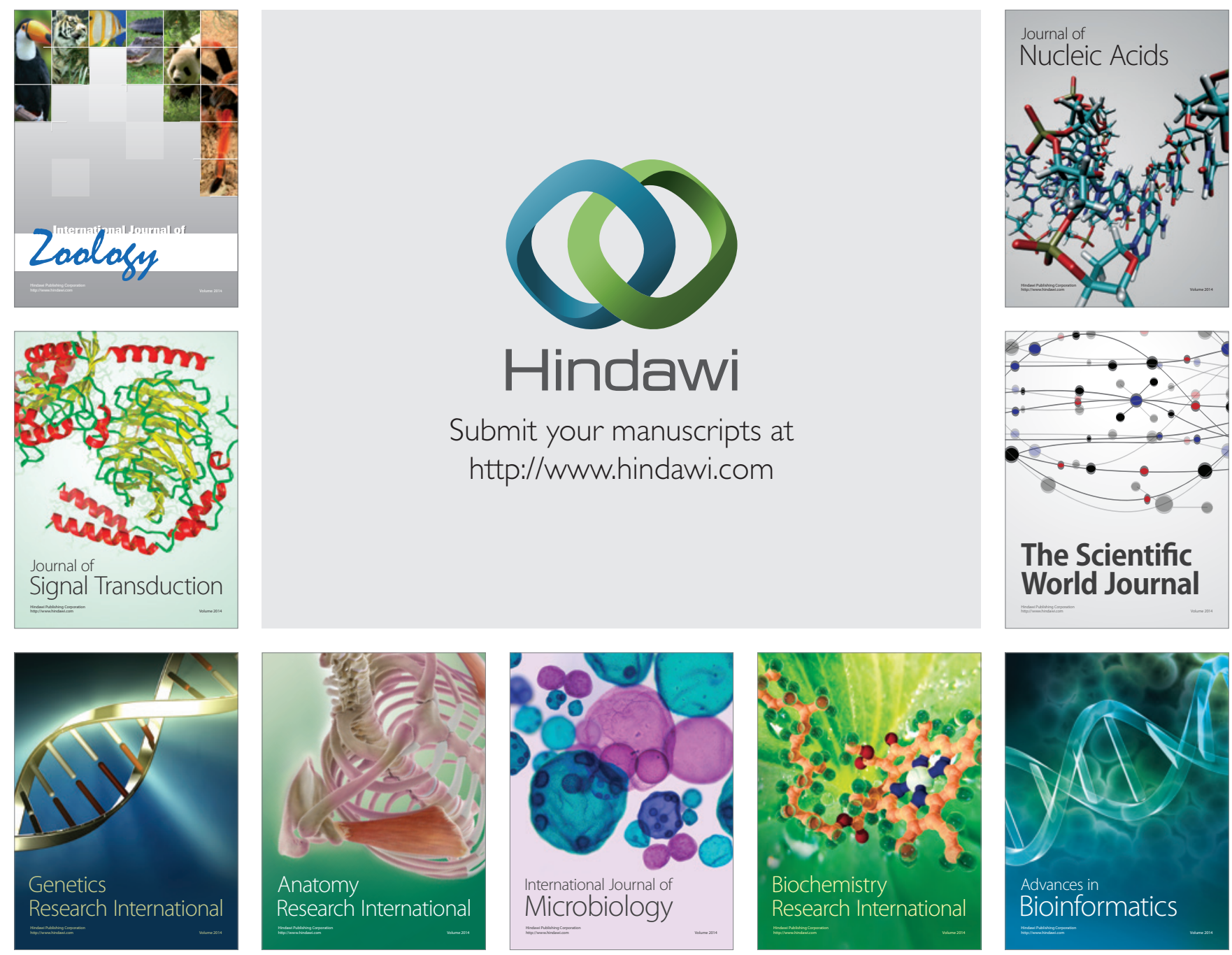

The Scientific World Journal
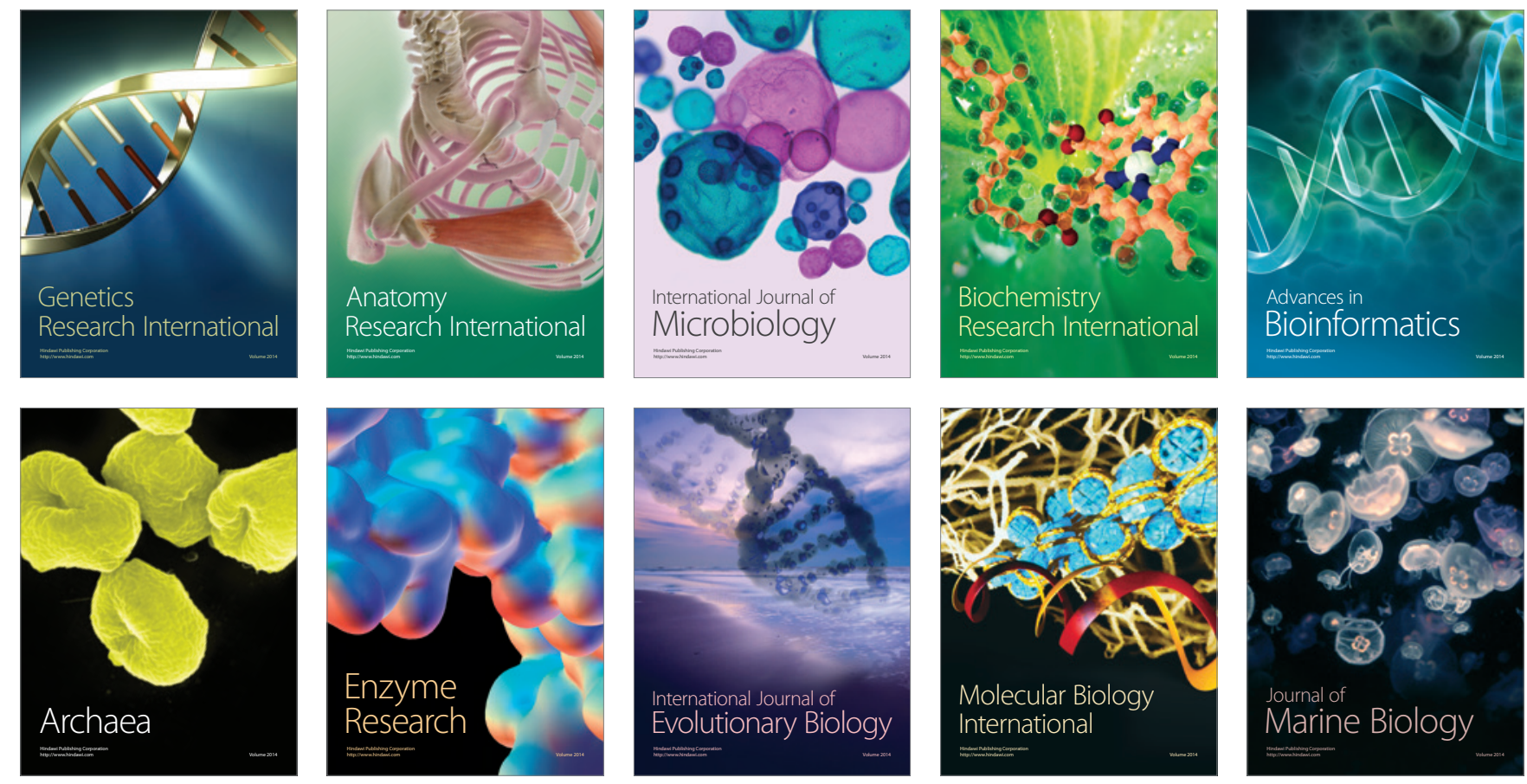